\title{
Investigation of the effects of estrogen on skeletal gene expression during zebrafish larval head development
}

Ehsan Pashay Ahi, Benjamin S Walker, Christopher S Lassiter, Zophonías O Jónsson

The development of craniofacial skeletal structures requires well-orchestrated tissue interactions controlled by distinct molecular signals. Disruptions in normal function of these molecular signals have been associated with a wide range of craniofacial malformations. A pathway mediated by estrogens is one of those molecular signals that plays role in formation of bone and cartilage including craniofacial skeletogenesis. Studies in zebrafish have shown that while higher concentrations of $17-\beta$ estradiol $\left(E_{2}\right)$ cause severe craniofacial defects, treatment with lower concentrations result in subtle changes in head morphology characterized with shorter snout and flatter face. The molecular basis for these morphological changes, particularly the subtle skeletal effects mediated by lower $E_{2}$ concentrations, remains unexplored. In the present study we address these effects at a molecular level by quantitative expression analysis of sets of candidate genes in developing heads of zebrafish larvae treated with two different $E_{2}$ concentrations. To this end, we first validated three suitable reference genes, ppia2, rp/8 and tbp, to permit sensitive quantitative real-time PCR analysis. Next, we profiled the expression of 28 skeletogenesis-associated genes that potentially respond to estrogen signals and play role in craniofacial development. We found $E_{2}$ mediated differential expression of genes involved in extracellular matrix (ECM) remodelling, mmp2/9/13, sparc and timp2a, as well as components of skeletogenic pathways, bmp2a, erf, ptch1/2, rankl, rarab and sfrpla. Furthermore, we identified a co-expressed network of genes, including cpn1, dnajc3, esr1, Iman1, rrbpla, ssr1 and tram1 with a stronger inductive response to a lower dose of E2 during larval head development. 


\section{Investigation of the effects of estrogen on skeletal gene}

\section{2 expression during zebrafish larval head development}

3

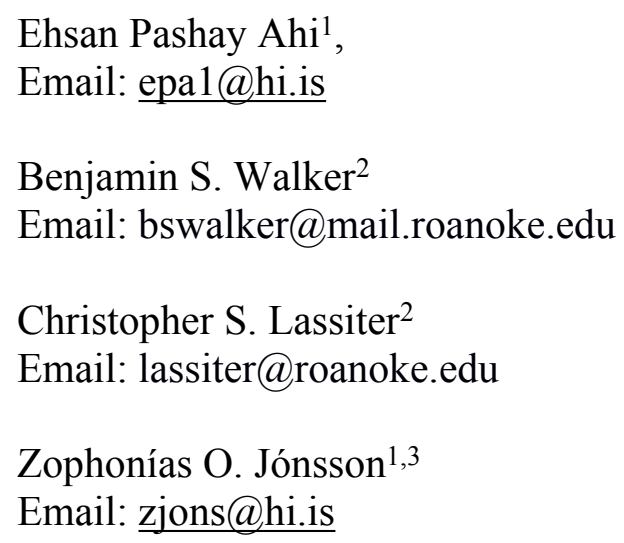

\section{Abstract}

The development of craniofacial skeletal structures requires well-orchestrated tissue interactions controlled by distinct molecular signals. Disruptions in normal function of these molecular signals have been associated with a wide range of craniofacial malformations. A pathway mediated by estrogens is one of those molecular signals that plays role in formation of bone and cartilage including craniofacial skeletogenesis. Studies in zebrafish have shown that while higher concentrations of 17- $\beta$ estradiol $\left(E_{2}\right)$ cause severe craniofacial defects, treatment with lower concentrations result in subtle changes in head morphology characterized with shorter snout and flatter face. The molecular basis for these morphological changes, particularly the subtle skeletal effects mediated by lower $\mathrm{E}_{2}$ concentrations, remains unexplored. In the present study we address these effects at a molecular level by quantitative expression analysis of sets of candidate genes in developing heads of zebrafish larvae treated with two different $\mathrm{E}_{2}$ concentrations. To this end, we first validated three suitable reference genes, ppia $2, r p l 8$ and $t b p$, to permit sensitive 
quantitative real-time PCR analysis. Next, we profiled the expression of 28 skeletogenesisassociated genes that potentially respond to estrogen signals and play role in craniofacial development. We found $\mathrm{E}_{2}$ mediated differential expression of genes involved in extracellular matrix (ECM) remodelling, mmp2/9/13, sparc and timp $2 a$, as well as components of skeletogenic pathways, bmp2a, erf, ptch1/2, rankl, rarab and sfrpla. Furthermore, we identified a co-expressed network of genes, including cpn1, dnajc3, esr1, lman1, rrbpla, ssr1 and tram1 with a stronger inductive response to a lower dose of $E_{2}$ during larval head development.

\section{Introduction}

Craniofacial development is a critical part of embryogenesis and identification of molecular mechanisms underlying this process is important in gaining a better understanding of morphological diversity in vertebrates (Szabo-Rogers et al., 2010) as well as human health (Oginni \& Adenekan, 2012). The viscerocranium in humans is of interest because of oro-facial clefts and associated malformations (Marazita, 2012). The vertebrate craniofacial skeleton, including the viscerocranium, is built from neural-crest derived tissues. Changes in these tissues over evolutionary time have given rise to a wide diversity of facial morphologies among vertebrate species (Trainor, Melton \& Manzanares, 2003; Bronner \& LeDouarin, 2012).

Estrogens, steroid hormones synthesized by aromatase from androgenic precursors, have recently been shown to affect craniofacial development (Fushimi et al., 2009; Cohen et al., 2014). Though estrogens are normally thought of as sex hormones, they affect a variety of tissues including the cardiovascular and skeletal systems (Hall, Couse \& Korach, 2001; Allgood et al., 2013; Cohen et al., 2014). Estrogens signal through classical nuclear receptors (ER-alpha and ER-beta) (Jia, Dahlman-Wright \& Gustafsson, 2015) and a G-protein coupled receptor, GPR-30 (Jenei-Lanzl et al., 2010). These signaling proteins are found in the chondrocytes of many vertebrate species (Tankó et al., 2008) and are present during chondrogenesis (Jenei-Lanzl et al., 2010; Elbaradie et al., 2013). Among vertebrates, teleost fish are highly diversified in craniofacial morphology and estrogen has been shown to greatly affect chondrogenesis in many of the fish species studied so far, including tilapia, fathead minnow, and zebrafish ( $\mathrm{Ng}$, Datuin \& Bern, 2001; Warner \& Jenkins, 2007; Cohen et al., 2014). Furthermore, the teleost zebrafish is a well-developed model system for studying both embryonic development and human disease and 
65 it can be useful in understanding the development of the human viscerocranial skeleton as these 66 processes are well-conserved among vertebrates (Kuratani, Matsuo \& Aizawa, 1997).

67 Low concentrations of estrogen cause subtle changes in craniofacial morphogenesis during zebrafish larval development (Cohen et al., 2014). These changes are characterized by a shorter snout, flatter face and wider angles of cartilage elements in the viscerocranium (Cohen et al., 2014). Another recent study has also demonstrated that an estrogen mediated signal underlies the evolution of shorter snouts and flatter faces in females of some reptilian species (Sanger et al., 2014). These observations suggest that similar mechanisms might underpin hormone-based phenotypic plasticity and diversity (Dufty, 2002), as well as subtle differences in head/skeletal morphology of dimorphic sexes (Loth \& Henneberg, 2001; Fujita et al., 2004; Callewaert et al., 2010). Therefore, studies offering insights into molecular mechanisms rendering the observed phenotypes caused by hormonal changes would be called for.

The subtle changes in craniofacial skeletogenesis mediated by low concentrations of Estradiol $\left(\mathrm{E}_{2}\right)$ are likely to be a result of differences in level and timing of the expression of skeletogenesis-associated genes during head development (Albertson et al., 2010; Ahi et al., 2014; Gunter, Koppermann \& Meyer, 2014; Powder et al., 2015). These morphological changes were only revealed by careful measurements of skeletal elements at zebrafish larval stages (Cohen et al., 2014), therefore the identification of responsible genes might also require precise expression studies in developing heads of zebrafish larvae using a sensitive tool such as quantitative real-time PCR (qPCR) (Bustin, 2000; Kubista et al., 2006). In the present study, we set out to quantitatively assess the effects of estrogen on the expression dynamics of candidate genes which are known as potential targets of estrogen pathway and also involved in craniofacial skeletogenesis in different vertebrate species (Table 1). We hypothesized that these genes may be critical to the estrogen modulation of craniofacial skeletogenesis. We first identified the most stably expressed reference genes in developing heads of zebrafish treated with two doses of estrogen $(2 \mu \mathrm{M}$ and $5 \mu \mathrm{M})$ across five stages in larval development. Then, we accurately measured small changes in the expression levels of the candidate genes. In addition, we have used available co-expression data from zebrafish to identify a co-expressed network of genes with greater transcriptional response to the lower dose of estrogen $(2 \mu \mathrm{M})$ during larval head development. 
96

97

98

99

100

101

102

103

104

105

106

107

108

109

110

111

112

113

114

115

116

117

118

119

120

121

122

123

124

\section{Methods}

\section{Fish husbandry, treatment and sampling}

Adult zebrafish were fed a diet of live brine shrimp supplemented with Ziegler zebrafish diet (Pentair) and maintained on a 14/10 day/night cycle. Embryos were raised in E3B (5 mM NaCl, $0.17 \mathrm{mM} \mathrm{KCl}, 0.33 \mathrm{mM} \mathrm{CaCl}_{2}, 0.33 \mathrm{mM} \mathrm{MgSO}{ }_{4}, 0.00025 \%$ methylene blue). Embryos were treated with estrogen (17ß-estradiol, $\mathrm{E}_{2}$, Sigma) dissolved in ethanol and diluted in E3B for a final ethanol concentration of $0.1 \%$. Control fish were treated with $0.1 \%$ ethanol with no developmental malformations as described previously (Cohen et al., 2014). For each treatment group (estrogen concentration), zebrafish larva were raised in Petri dishes, and treatment solutions were refreshed daily until the stages indicated $(3,4,5,6$ and 7 days post fertilization, dpf). Three biological replicates of 30 larva were collected at each time-point (3-7 dpf) and for each treatment group (control, $2 \mu \mathrm{M} \mathrm{E}_{2}$, and $5 \mu \mathrm{M} \mathrm{E}_{2}$ ) for a total of 90 larva at each time-point and treatment. The fishes were anesthetized with $0.4 \%$ tricaine (MS-222, Sigma). Isolated heads (anterior to the yolk sac) were placed into RNAlater (Qiagen) and stored frozen until RNA isolation. Zebrafish experiments were performed under the Roanoke College IRB protocol \#14BIO76.

\section{RNA isolation and cDNA synthesis}

Around 30 heads of zebrafish from each treatment group and larval stage were pooled in TRI Reagent (Sigma) and homogenized with a disposable Kontes Pellet Pestle Cordless Motor tissue grinder (Kimble Kontes). RNA was prepared according to manufacturer's instructions and dissolved in $50 \mu 1$ RNase-free water. RNA samples were treated with DNase (New England Biolabs) to remove contaminating DNA. Quantity of the resulting RNA samples was assessed using a NanoDrop ND-1000 UV/Vis-Spectrophotometer (NanoDrop Technologies). The quality of the RNA samples was evaluated by agarose gel electrophoresis and all samples displayed intact $28 \mathrm{~S}$ and $18 \mathrm{~S}$ rRNA without noticable high molecular weight genomic DNA contamination. cDNA was prepared from 1000 ng of RNA using the High capacity cDNA Reverse Transcription kit (Applied Biosystems), according to manufacturer's protocol. Several samples without addition of reverse transcriptase (-RT samples) were prepared to confirm the 
125 absence of genomic DNA. cDNA was diluted 3 fold in water for further use in quantitative real126 time PCR.

127

\section{Gene selection, Primer design and real-time qPCR}

129 In order to validate suitable reference genes for accurate measurement of the transcriptional 130 changes of candidate genes by qPCR, we selected 7 potential reference genes based on published 131 studies in zebrafish (Table S1) (McCurley \& Callard, 2008; Pelayo et al., 2012; Schiller et al., 132 2013), none of which have been validated during development or in zebrafish head. In addition 133 we selected 28 target genes that are known as potential targets of the estrogen pathway in 134 different vertebrate species, and also involved in craniofacial skeletal formation/morphogenesis 135 (Table 1 and Table S1). Finally, we extended our list of candidates by adding more genes 136 showing co-expression with the estrogen receptor esrl based on the zebrafish database 137 COXPRESdb (http://coxpresdb.jp/) version 6.0 (Obayashi \& Kinoshita, 2011). To obtain the 138 maximum number of coexpressed genes with a high degree of reliability, we filtered the genes 139 by setting the mutual rank (MR) to the top-ranked 2000 and the Supportability score of minimum 1401 (as described by Obayashi and Kinoshita, 2011). This yielded 338 candidate genes, and from 141 them, we selected 11 genes with reported craniofacial expression during zebrafish development 142 according to the ZFIN database (http://zfin.org) (Bradford et al., 2011) (Table S1).

143 Locations overlapping exon boundaries of the genes in zebrafish were determined by NCBI 144 Spidey software (www.ncbi.nlm.nih.gov/spidey) and annotated genome sequences in the 145 Ensembl database (http://www.ensembl.org/Danio rerio). The qPCR Primers were designed on 146 exon boundaries using Primer Express 3.0 software (Applied Biosystems, Foster City, CA, USA) 147 and checked for self-annealing, hetero-dimers and hairpin structures with OligoAnalyzer 3.1 148 (Integrated DNA Technology) (Table S1).

149 Real-time PCR was performed in 96 well-PCR plates on an ABI 7500 real-time PCR System 150 (Applied Biosystems) using Maxima SYBR Green/ROX qPCR Master Mix (2X) as 151 recommended by the manufacturer (Thermo Fisher Scientific, St Leon-Rot, Germany). Each 152 biological replicate was run in duplicate together with no-template control (NTC) in each run for 153 each gene and experimental set-up per run followed the preferred sample maximization method 154 (Hellemans et al., 2007). The qPCR was run with a 2 min hold at $50^{\circ} \mathrm{C}$ and a 10 min hot start at $15595^{\circ} \mathrm{C}$ followed by the amplification step for 40 cycles of $15 \mathrm{sec}$ denaturation at $95^{\circ} \mathrm{C}$ and $1 \mathrm{~min}$ 
156 annealing/extension at $60^{\circ} \mathrm{C}$. A dissociation step $\left(60^{\circ} \mathrm{C}-95^{\circ} \mathrm{C}\right)$ was performed at the end of the 157 amplification phase to identify a single, specific product for each primer set (Table S1). Primer 158 efficiency values (E) were calculated with the LinRegPCR v11.0 programme 159 (http://LinRegPCR.nl) (Ramakers et al., 2003) analysing the background-corrected fluorescence 160 data from the exponential phase of PCR amplification for each primer-pair and those with E less 161 than 0.9 were discarded and new primers designed (Table S1).

162

\section{Data analysis}

164 To detect the most stably expressed reference genes, three ranking algorithms; BestKeeper 165 (Pfaffl et al., 2004), NormFinder (Andersen, Jensen \& Ørntoft, 2004) and geNorm 166 (Vandesompele et al., 2002), were employed. The standard deviation (SD) based on Cq values of 167 the larval stages and treatment groups was calculated by BestKeeper to determine the expression 168 variation for each reference gene. In addition, BestKeeper determines the stability of reference 169 genes based on correlation to other candidates through calculation of BestKeeper index (r). GeNorm measures mean pairwise variation between each gene and other candidates, the expression stability or $M$ value, and it excludes the gene with the highest $M$ value (least stable) from subsequent analysis in a stepwise manner. Moreover, geNorm determines the optimal number of reference genes through calculation of pairwise variation coefficient $(\mathrm{Vn} / \mathrm{n}+1)$ between two sequential normalisation factors (NFn and NFn+1) and extra reference genes are added until the variation drops below the recommended threshold of 0.15 (Vandesompele et al., 2002). NormFinder identifies the most stable genes (lowest expression stability values) based on analysis of the sample subgroups (stage and treatment group) and estimation of inter- and intragroup variation in expression levels.

For the analysis of qPCR data, the difference between $\mathrm{Cq}$ values $(\triangle \mathrm{Cq})$ of the reference genes and the target genes was calculated for each gene; $\Delta \mathrm{Cq}$ target $=\mathrm{Cq}$ target $-\mathrm{Cq}$ reference. The geometric mean of $\mathrm{Cq}$ values of three best ranked reference genes, ppia2, $r p l 8$ and $t b p$ (see the ranking algorithms above), was used as $\mathrm{Cq}$ reference in the $\Delta \mathrm{Cq}$ calculations. All samples were then normalized to the $\Delta \mathrm{Cq}$ value of a calibrator sample to obtain a $\Delta \Delta \mathrm{Cq}$ value $(\Delta \mathrm{Cq}$ target $-\Delta \mathrm{Cq}$ calibrator). For each primer pair a biological replicate in the control group at $3 \mathrm{dpf}$ was selected as the calibrator sample. Relative expression quantities (RQ) were calculated based on the 186 expression level of the calibrator sample $\left(\mathrm{E}^{-\Delta \Delta \mathrm{Cq}}\right)$ (Pfaffl, 2001). The RQ values were then 
187 transformed to logarithmic base 2 values (or fold differences; FD) for statistical analysis 188 (Bergkvist et al., 2010). A two-way analysis of variance (ANOVA) followed by post hoc Tukey's 189 honest significant difference (HSD) test was implemented for each reference or target gene with 190 larval stages and treatment groups as categorical variables. To assess similarities in expression 191 patterns of the genes Pearson correlation coefficients $(r)$ were calculated for all gene pairs using 192 the data from 3 treatments at 5 larval stages (degree of freedom = 13). R (http://www.r193 project.org) was used for all statistical analysis.

\section{Results}

197

\section{tbp, ppia2 and $r p l 8$ are the most suitable reference genes}

Real-time quantitative PCR for the 7 reference gene candidates was performed on cDNA generated from zebrafish head homogenates in three treatment groups at five larval stages. The expression levels of the candidates varied from ppia2, with the highest expression (lowest $\mathrm{Cq}$ ) (Fig. 1A), to $t b p$ with the lowest expression (highest Cq). Statistical analysis revealed that all of the candidates except $a c t b 1$ are stably expressed between the treatment groups (Fig. 1B). However, only tbp showed constant expression during the larval stages examined. Two genes, ppia 2 and rpl8, were also stably expressed in developing heads of zebrafish larvae except for the first stage (3dpf). Based on these results $t b p$ followed by ppia 2 and $r p l 8$ were found to be the overall most stable reference genes both over time and between the treatment groups. The candidate reference genes were ranked using three algorithms, i.e. BestKeeper, geNorm and NormFinder, and based on standard deviation (SD) as described in (Ahi et al., 2013) (Table 2). In all of the analyses three genes; ppia,$r p l 8$ and $t b p$, were the three highest ranking candidates, however their order varied between the rankings (Table 2). Furthermore, geNorm suggested the use of the three best ranked candidate genes as sufficient for accurate normalisation (Fig. S1). The data reflect the high expression stability of the best ranked candidate genes and suggests the combination of ppia2, rpl8 and tbp as a suitable and sufficient normalization factor to accurately quantify small differences in gene expression in developing heads of zebrafish larvae across the $\mathrm{E}_{2}$ treatment groups. 
218 Components of different signalling pathways and skeletogenesis-associated 219 genes are affected by estrogen during larval head development

220 The selected 28 candidate target genes, listed in Table 1, can be classified into distinct functional 221 groups; (I) estrogen receptors with potential involvement in vertebrate craniofacial development 222 (esrra and esrl); (II) components of hedgehog (Hh) signaling pathway (ptch1/2 and shha/b); 223 (III) potential skeletogenic targets of estrogen pathway with critical roles in viscerocranial 224 development/ morphogenesis (bmp2a/b, opg, rankl, runx $2 b$ and sox $9 b$ ); (IV) potential targets of 225 estrogen pathway involved in ECM formation and associated with shortened snout 226 morphogenesis in vertebrates (col2ala, ctsk, mmp2/9/13, sparc, spp1 and timp2a); and (V) other 227 potential targets of estrogen pathways with diverse functions which are also involved in 228 viscerocranial skeletogenesis (alx4, dlk1, erf, ets2, pbxla/b, rarab and sfrpla). The expression 229 levels of all candidates were measured in the three treatment groups during larval head 230 development (Fig. 2-5). We found effects of different $E_{2}$ concentrations on the expression of 231 most of the target genes, except col2ala and pbxla, the effects, however, were highly variable 232 among the genes (Fig. 2-5). For instance, while some genes, i.e. esrl, ptch1/2 and rarab displayed differential expression between the treatment groups at most of the larval stages, other genes such as alx4, bmp2b, ctsk, ets2, opg, etc., showed expression differences at only one stage. Among the more highly affected genes, erf, esrra, mmp9, rankl, shha, sfrpla, sparc and timp $2 a$ were differentially expressed in at least three larval stages (Fig. 2-5). Although significant, most differences in expression levels of the target genes were slight between the treatment groups (RQ $<0.5$ ), except for esrl at the last larval stages (Fig. 2). Moreover, for all of the affected genes, except esrl and mmp13, the different $\mathrm{E}_{2}$ treatments had mainly repressive effects on transcription. These repressive effects were not, however, increased by higher $\mathrm{E}_{2}$ concentration particularly at the last two stages when the lower $E_{2}$ dose $(2 \mu \mathrm{M})$ repressed expression of many of the genes more than the higher dose. At the last three stages, the expression of esrl was induced at highest levels for $2 \mu \mathrm{M}$ treatment groups (Fig. 2). The transcriptional repression by $\mathrm{E}_{2}$ was also variable between the genes and it was more pronounced for erf and ptch2 showing higher expression in control groups than both $\mathrm{E}_{2}$ treated groups at three larval stages. Taken together, these results show significant effects of low $E_{2}$ concentrations on the expression of a variety of genes involved in skeletogenesis and/or craniofacial development. 
248 We calculated the Pearson's correlation coefficient of the expression levels for the target genes

249 over all treatment groups and larval stages and found positive expression correlation between 250 many pairs of target genes (blue shadings in Fig. S2). Some of the genes i.e. mmp9, ptch1, rarab

251 and timp2a displayed positive expression correlation with most of the genes whereas others such

252 as mmp13, sfrpla, shhb and sparc showed the least correlated expression. Negatively correlated 253 expression was only seen between esrl and sfrpla, and between shhb and six genes including 254 esrl, ets2, mmp13, opg, pbxla and spp1 (red shadings in Fig. S2).

255

256

257

A co-expressed network of genes shows higher expression induction in lower $\mathbf{E}_{2}$ treatment groups

258 The stronger transcriptional response of esrl to the lower $E_{2}$ treatment (Fig. 2) could indicate a 259 distinct regulatory mechanism associated with slight increase in estrogen concentration during

260

261

262

263

264

265

266

267

268

269

270

271

272

273

274

275

276

277 zebrafish larval head development. In order to identify additional genes showing similar expression dynamics, we selected 11 candidate genes constructing a co-expression network with esrl using co-expression data for zebrafish in COXPRESdb (Obayashi \& Kinoshita, 2011) (Table S2). These candidates are also known to have craniofacial skeletal expression during zebrafish development based on data submitted to ZFIN database (http://zfin.org) (Bradford et al., 2011). Strikingly, we found stronger inductive effects of the lower $E_{2}$ concentration on the expression of six genes, i.e. cpn1, dnajc3, Iman1, rrbpla, ssr1 and traml (Fig. 6). The expression of these six genes followed a similar pattern and their higher expression levels were more pronounced at the last three stages of $2 \mu \mathrm{M}$ treatment groups. Moreover, the gene showing strongest coexpression relationship with esrl among the candidates, rrbpla, had shown higher expression levels at the last four stages of $2 \mu \mathrm{M}$ treatment groups (Table S2 and Fig. 6). Finally, we also demonstrated positive expression correlations between the six candidates and esrl, but not the rest of the non-differentially expressed genes (blue shadings in Fig. S3).

\section{Discussion}

Estrogen signaling, through both canonical nuclear estrogen receptors and G-protein coupled receptors, is important in embryonic development (Griffin et al., 2013; Shi et al., 2013). Estrogens can act at autocrine, paracrine, and endocrine distances in the embryo and the adult 
278 (Boon, Chow \& Simpson, 2010). Aromatase, the enzyme that synthesizes estrogens, is present in 279 the developing brain of many species, including zebrafish (Lassiter \& Linney, 2007) and would 280 be a local source of the hormone during head development. In fact, the teleost brain produces 281 relatively high levels of estrogen compared to other vertebrates (Forlano et al., 2001). Estrogens 282 are thus present in the cranium of developing embryos and modulate viscerocranial development 283 (Fushimi et al., 2009; Marquez Hernandez et al., 2011; Cohen et al., 2014). Estrogen signalling 284 has been implicated in the sexual dimorphism of cranial bones in the Anolis lizard (Sanger et al., 285 2014). Hence, it may play a role in craniofacial morphological divergence among species and 286 within sexes of the same species.

287 A previous attempt to identify mechanisms underlying the effects of estrogen on zebrafish 288 craniofacial development was conducted with a high concentration of 17- $\beta$ estradiol $(10 \mu \mathrm{M})$ 289 giving rise to major disruptions of chondrogenesis followed by severe morphological defects 290 (Fushimi et al., 2009). In the same study, analysis of gene expression after high dose estrogen 291 treatment was limited to a semi-quantitative method (in situ hybridization) and a few 292 chondrogenic genes belonging to only one molecular pathway (Fushimi et al., 2009). We 293 hypothesized that many other candidate genes would be involved and hence, in the present study, 294 we sought to quantitatively assess the expression of genes that could play role in the subtle 295 effects of estrogen on the development of the craniofacial skeleton in zebrafish larvae (Cohen et 296 al., 2014). Since our expression analysis depended on accurate qPCR, a prior step of careful 297 validation of reference genes was essential to acquire reliable results (Bustin, 2000; Kubista et 298 al., 2006). An increasing number of stably expressed reference genes have been validated for 299 qPCR studies in a variety of fish species (Ahi et al., 2013; Fuentes et al., 2013; Liu et al., 2014; 300 Altmann et al., 2015; Wang et al., 2015), and also in zebrafish at different developmental stages, 301 body parts/tissues, and treatments (Tang et al., 2007; McCurley \& Callard, 2008; Lin et al., 302 2009; Casadei et al., 2011). There is however a necessity for validation of reference genes depending on the experimental conditions under study. Here, we found three genes, ppia2, rpl8 and $t b p$, to be the most stably expressed candidate genes by all the methods of analysis used (Table 2 and Fig.1) and their combination could ensure robust qPCR data normalisation (Fig. S1). We next selected candidate genes that are shown to be potential estrogen pathway targets, and at the same time, differential regulation of many of them is associated with morphological 308 changes resembling shortened snout in different vertebrates (many found in mammalian species) 
309 (see publications referenced in Table 1). The underlying mechanisms by which these candidate 310 genes could affect skeletogenesis are different from each other. For instance, genes like $b m p 2 a / b$, 311 rankl, runx $2 b$ and sox $9 b$ are major factors in differentiation of skeletal cells and some others 312 such as col2ala, ctsk, mmp2/9/13, sppl and sparc are critical for the formation of ECM in 313 craniofacial skeletal structures (see Table 1).

314 The treatments with the two different doses of $E_{2}(2$ and $5 \mu \mathrm{M})$ resulted in differential expression 315 of many of the candidates during the zebrafish larval head development (Fig. 2-5). Consistent 316 with a previous study in zebrafish using higher $\mathrm{E}_{2}$ concentration (10 $\left.\mu \mathrm{M}\right)$ (Fushimi et al., 2009), 317 we also found significant down-regulation of ptch1 and ptch2 in the heads of fish receiving 318 lower dose estrogen treatments during larval development. These two genes are the receptors 319 (and the upstream mediators) of the hedgehog $(\mathrm{Hh})$ signaling pathway which plays a crucial role 320 in developmental patterning and skeletal morphogenesis (Eberhart et al., 2006; Swartz et al., 321 2012). Interestingly, slight changes in expression of ptchl were shown to be associated with 322 subtle craniofacial skeletal divergence (shorter snout and flatter face) in cichlid fish (Roberts et 323 al., 2011; Hu \& Albertson, 2014). In addition, we found a strong positive expression correlation 324 between ptch1 and ptch2 (Fig. S2), indicating potential estrogen mediated co-regulation of the 325 two $\mathrm{Hh}$ receptors. In the above mentioned study of high dose $\mathrm{E}_{2}$ treatment, the upstream 326 activators of the Hh pathway, sonic hedegehog genes, shha and shhb (twhh), did not show 327 significant changes in expression (Fushimi et al., 2009). However, this could be due to technical 328 limitations such as the use of a semi-quantitative method that is unable to reveal small 329 differences in gene expression (Fushimi et al., 2009). In this study we found small and yet 330 significant down-regulation of $s h h a$, but not $s h h b$, in $\mathrm{E}_{2}$ treated groups, as well as positive co331 expression of only shha with the two Hh receptors. An important role of the shh in craniofacial 332 skeletogenesis through activation of Hh signalling has been described (Hu \& Helms, 1999), but it 333 is not clear whether estrogen directly regulates its expression during development. The small 334 reduction of shha transcripts in developing larval heads might be a result of a decreased number 335 of cells expressing shha and not direct estrogen mediated transcriptional regulation.

336 Extracellular matrix remodelling is a critical process in the developmental program of bone and 337 cartilage differentiation and morphogenesis (Werb \& Chin, 1998). The spatio-temporal 338 expression of genes encoding matrix metalloproteinases and their tissue inhibitors plays a pivotal 339 role in orchestrating the ECM remodelling process (Werb \& Chin, 1998; Page-McCaw, Ewald \& 
340 Werb, 2007). Moreover, many ECM remodelling genes are downstream targets of pathways 341 mediated by nuclear receptors, including estrogen signalling (Cox \& Helvering, 2006; Heldring 342 et al., 2007; Ganesan et al., 2008). The selected ECM remodelling factors (mmp2/9/13, timp2a 343 and sparc) were all reported to be regulated by estrogen signalling (Lehane et al., 1999; Tüshaus 344 et al., 2003; Marin-Castaño et al., 2003; Lu et al., 2006; Nilsson, Garvin \& Dabrosin, 2007; Lam 345 et al., 2009; Wang \& Ma, 2012) and play role in craniofacial skeletal morphogenesis (Dew et al., 346 2000; Renn et al., 2006; Hillegass et al., 2007a,b; Mosig et al., 2007; Rotllant et al., 2008; Letra 347 et al., 2012; Ahi et al., 2014). Our results revealed slight but significant effects of the estrogen 348 treatments on expression of the selected ECM remodelling genes during larval head development 349 (Fig. 4). It is interesting to note that previous investigations have shown association between 350 differential expression of these genes and craniofacial phenotypes with flatter face and shorter 351 snout (Hillegass et al., 2007a,b; Ahi et al., 2014). The mechanism by which estrogen regulates 352 the expression of ECM remodelling genes is not well understood. The estrogen dependent 353 regulation might be exerted through interaction between estrogen-receptors and transcription 354 factors that regulate ECM remodelling genes such as members of Ap-1 complex and ETS factors 355 (Lu et al., 2006; Ahi et al., 2014; Cao et al., 2015). The binding motifs for Ap-1 and ETS 356 transcription factors are present in the promoters of many ECM remodelling genes across 357 vertebrate species (Ahi et al., 2014). Additionally, we found the expression of erf, an ETS 358 repressor and estrogen target (Sgouras et al., 1995), to be down-regulated in both $\mathrm{E}_{2}$ treated 359 groups at three larval stages. Remarkably, a recent study showed that small reduction in 360 expression of erf causes complex craniosynostosis with shortened snout in both human and mice 361 (Frasor et al., 2003; Twigg et al., 2013). The same study also demonstrated regulatory elements 362 containing Ap-1, ETS and Runx motifs as preferential erf binding sites (Twigg et al., 2013). 363 Taken together, the results of the present and previous studies suggest potential estrogen 364 mediated regulation of ECM remodelling genes possibly through interaction with other 365 transcription factors. Other estrogen mediated processes than direct transcriptional regulation 366 cannot, however, be ruled out, as the slight changes in transcript levels of ECM related genes 367 could be due to reduced proportion of skeletal cells expressing these genes in larval heads. It is 368 also important to emphasize that the selected ECM genes can be expressed in other tissues of the 369 head (though at considerably lower levels), thus their expression differences in other tissues 370 might affect the overall changes in expression. 
371 The $E_{2}$ treatments caused small and variable repressive effects on expression of other selected

372 target genes (Fig. 2-5). The genes, bmp2a and rankl, are well characterized skeletogenic markers

373 (Nie, Luukko \& Kettunen, 2006; Hu, Colnot \& Marcucio, 2008; Lézot et al., 2015) and their

374 regulation by estrogen signalling has been reported in other vertebrate species (Bord et al., 2003;

375 Zhou et al., 2003). It has been shown that treatment with high doses of $\mathrm{E}_{2}$ can reduce the number

376 of skeletal cells in the craniofacial skeleton (Cohen et al., 2014), hence the small changes in

377 transcript levels of skeletogenic markers (e.g. sox $9 b$ ) may again be caused by a decreased

378 proportion of skeletal cells in the heads. We also found components of retinoic acid and Wnt/ $\beta$ -

379 catenin signalling patways, rarab and sfrpla, to be transcriptionally affected by $\mathrm{E}_{2}$ treatment

380 indicating the potential crosstalk of these pathways with estrogen signalling during larval head

381 development (Lohnes et al., 1994; O’Lone et al., 2004; Trevant et al., 2008; Yokota et al., 2008).

382 Although, the selected components of the pathways and transcription factors in this study (Fig. 5)

383 are known to have markedly high levels of expression in the craniofacial skeleton, they might

384 also be expressed to a lesser extent in other tissues within the larval head. Therefore, the

385 observed small changes in expression can not be readily attributed to viscerocranial skeletal

386 elements and further gene expression studies using dissected skeletal elements are essential to

387 confirm this.

388 In addition to skeletogenic genes, we were interested in investigating the effects of different 389 doses of $E_{2}$ on the expression of estrogen receptors. Therefore, we assessed the expression of two 390 estrogen receptors, esrra and esrl, that could mediate estrogen signal during the development of 391 skeletal tissues (Bonnelye \& Aubin, 2005; Bonnelye et al., 2007; Auld et al., 2012). While the $E_{2}$ 392 treatments had small and variable repressive effects on expression of esrra, the increased 393 expression of esrl was observed in both $\mathrm{E}_{2}$ treated groups. Strikingly, the lower $\mathrm{E}_{2}$ concentration $394(2 \mu \mathrm{M})$ resulted in higher induction of esrl expression. This suggests that the distinct effects of 395 lower doses of estrogen on craniofacial skeletogenesis, described by Cohen et al., 2014, might be 396 mediated by esr l, however further functional studies are required to demonstrate such a role. To 397 identify genes sharing regulatory mechanisms in response to slight increases in estrogen levels, 398 we further explored the expression of 11 genes constructing a co-expression network with esrl 399 (Table S2 and Fig. 6). These candidate genes were selected by using a vertebrate co-expression 400 database (Obayashi \& Kinoshita, 2011) which we have successfully used for identification of 401 gene networks associated with subtle craniofacial morphological divergence in another teleost 
402 (Ahi et al., 2014, 2015). Our results indicate higher transcriptional induction of six genes, i.e. 403 cpn1, dnajc3, lman1, rrbpla, ssr1 and tram1 in the lower $(2 \mu \mathrm{M})$, than the moderate $(5 \mu \mathrm{M})$ 404 treatment groups, during craniofacial development. The genes also showed positive expression 405 correlation with esrl suggesting a common regulatory mechanism mediated by estrogen during 406 head development. To our knowledge, a mechanism by which a lower concentration of estrogen 407 can have stronger inductive effects on expression of certain genes than higher concentrations is 408 not known. Such a mechanism might be involved in distinct regulation of estrogen receptors by 409 different concentrations of estrogen hormone, which in turn could lead to recruitment of the 410 receptors to distinct genomic binding sites and/or with different binding affinity (Stender et al., 411 2010). Among the six genes only dnajc3, a gene encoding protein kinase inhibitor P58 412 (P58 $\left.{ }^{\mathrm{IPK}}\right)$, has been shown to be involved in skeletogenesis through regulation of a cytokine413 dependent cartilage degradation (Gilbert et al., 2014). Although all of the six genes have 414 recorded developmental expression patterns in zebrafish craniofacial elements based on data in 415 the ZFIN zebrafish database (Thisse et al., 2001, 2004), their roles in craniofacial morphogenesis 416 have yet to be investigated. Finally, an unbiased approach such as transcriptome sequencing 417 rather than candidate gene-based study would be warranted to provide better knowledge of 418 estrogen mediated effects on expression of genes with unknown roles in craniofacial 419 morphogenesis as well as links between already identified genes and molecular pathways 420 involved.

421

\section{Conclusions}

423 In this study we quantitatively assessed the effects of two doses of estrogen $(2 \mu \mathrm{M}$ and $5 \mu \mathrm{M})$ on 424 gene expression during zebrafish larval head development. We performed a highly sensitive and specific qPCR analysis and carefully validated reference genes. We assessed the expression of a selected set of genes involved in craniofacial skeletal development as well as genes coexpressed with esrl, an estrogen receptor showing stronger inductive response to $2 \mu \mathrm{M}$ than $5 \mu \mathrm{M}$ estrogen concentration. The results implicate estrogen in the expressional regulation of genes belonging to distinct signalling pathways such as hedgehog and retinoic acid pathways, as well as genes involved in ECM remodelling during craniofacial development. Furthermore, estrogen mediated transcriptional changes in a few tested major skeletogenic factors (e.g. bmp2a and rankl), and a 432 transcription factor, erf, with a demonstrated role in the formation of a shortened snout 
433 phenotype in human and mouse. Finally, we identified a gene network showing positive 434 expression correlation with esrl and higher induction in response to treatment with $2 \mu \mathrm{M}$ than 435 with $5 \mu \mathrm{M}$ estrogen. This could suggest a co-regulated module of genes mediating the effects of 436 low doses of estrogen during craniofacial development which required to be further investigated 437 at functional level.

438

439

440

\section{Acknowledgements}

441

442

443

\section{4}

445

446

447

448

449

450

451

452

453

454

455

456

457

458

459

460

461

462

463

464

The authors would like to acknowledge Rebecca Hudon, Sean Ryan, and Alexander Kramer for assistance with zebrafish husbandry and sample isolation.

\section{References}

Abdallah BM., Ditzel N., Mahmood A., Isa A., Traustadottir GA., Schilling AF., Ruiz-Hidalgo M-J., Laborda J., Amling M., Kassem M. 2011. DLK1 is a novel regulator of bone mass that mediates estrogen deficiency-induced bone loss in mice. Journal of bone and mineral research: the official journal of the American Society for Bone and Mineral Research 26:1457-71.

Ahi EP., Guðbrandsson J., Kapralova KH., Franzdóttir SR., Snorrason SS., Maier VH., Jónsson ZO. 2013. Validation of Reference Genes for Expression Studies during Craniofacial Development in Arctic Charr. PloS one 8:e66389.

Ahi EP., Kapralova KH., Pálsson A., Maier VH., Gudbrandsson J., Snorrason SS., Jónsson ZO., Franzdóttir SR. 2014. Transcriptional dynamics of a conserved gene expression network associated with craniofacial divergence in Arctic charr. EvoDevo 5:40.

Ahi EP., Steinhäuser SS., Pálsson A., Franzdóttir SR., Snorrason SS., Maier VH., Jónsson ZO. 2015. Differential expression of the Aryl hydrocarbon receptor pathway associates with craniofacial polymorphism in sympatric Arctic charr. EvoDevo 6:27.

Albertson RC., Yan Y-L., Titus TA., Pisano E., Vacchi M., Yelick PC., Detrich HW., Postlethwait JH. 2010. Molecular pedomorphism underlies craniofacial skeletal evolution in Antarctic notothenioid fishes. BMC Evolutionary Biology 10:4.

Allgood OE., Hamad A., Fox J., Defrank A., Gilley R., Dawson F., Sykes B., Underwood TJ., Naylor RC., Briggs AA., Lassiter CS., Bell WE., Turner JE. 2013. Estrogen prevents cardiac and vascular failure in the "listless" zebrafish (Danio rerio) developmental model. 
466

467

468

469

470

471

472

473

474

475

476

477

478

479

480

481

482

483

484

485

486

487

488

489

490

491

492

493

494

495

496

497

498

Altmann S., Rebl A., Kühn C., Goldammer T. 2015. Identification and de novo sequencing of housekeeping genes appropriate for gene expression analyses in farmed maraena whitefish (Coregonus maraena) during crowding stress. Fish physiology and biochemistry 41:397412.

Andersen CL., Jensen JL., Ørntoft TF. 2004. Normalization of real-time quantitative reverse transcription-PCR data: a model-based variance estimation approach to identify genes suited for normalization, applied to bladder and colon cancer data sets. Cancer research 64:5245-50.

Auld KL., Berasi SP., Liu Y., Cain M., Zhang Y., Huard C., Fukayama S., Zhang J., Choe S., Zhong W., Bhat BM., Bhat RA., Brown EL., Martinez R V. 2012. Estrogen-related receptor $\alpha$ regulates osteoblast differentiation via $\mathrm{Wnt} / \beta$-catenin signaling. Journal of molecular endocrinology 48:177-91.

Bergkvist A., Rusnakova V., Sindelka R., Garda JMA., Sjögreen B., Lindh D., Forootan A., Kubista M. 2010. Gene expression profiling--Clusters of possibilities. Methods (San Diego, Calif.) 50:323-35.

Bonnelye E., Zirngibl RA., Jurdic P., Aubin JE. 2007. The Orphan Nuclear Estrogen ReceptorRelated Receptor- $\alpha$ Regulates Cartilage Formation in Vitro : Implication of Sox9. Endocrinology 148:1195-1205.

Bonnelye E., Aubin JE. 2005. Estrogen receptor-related receptor alpha: a mediator of estrogen response in bone. The Journal of clinical endocrinology and metabolism 90:3115-21.

Boon WC., Chow JDY., Simpson ER. 2010. The multiple roles of estrogens and the enzyme aromatase. Progress in brain research 181:209-32.

Bord S., Ireland D., Beavan S., Compston J. 2003. The effects of estrogen on osteoprotegerin, RANKL, and estrogen receptor expression in human osteoblasts. Bone 32:136-141.

Bradford Y., Conlin T., Dunn N., Fashena D., Frazer K., Howe DG., Knight J., Mani P., Martin R., Moxon SAT., Paddock H., Pich C., Ramachandran S., Ruef BJ., Ruzicka L., Bauer Schaper H., Schaper K., Shao X., Singer A., Sprague J., Sprunger B., Van Slyke C., Westerfield M. 2011. ZFIN: enhancements and updates to the Zebrafish Model Organism Database. Nucleic acids research 39:D822-9.

Breckon JJW., Papaioannou S., Kon LWM., Tumber A., Hembry RM., Murphy G., Reynolds JJ., Meikle MC. 1999. Stromelysin (MMP-3) Synthesis Is Up-Regulated in Estrogen-Deficient Mouse Osteoblasts In Vivo and In Vitro. Journal of Bone and Mineral Research 14:1880 1890. 
499

500

501

502

503

504

505

506

507

508

509

510

511

512

513

514

515

516

517

518

519

520

521

522

523

524

525

526

527

528

529

530

531

532

Bronner ME., LeDouarin NM. 2012. Development and evolution of the neural crest: an overview. Developmental biology 366:2-9.

Bustin S. 2000. Absolute quantification of mRNA using real-time reverse transcription polymerase chain reaction assays. Journal of Molecular Endocrinology 25:169-193.

Callewaert F., Sinnesael M., Gielen E., Boonen S., Vanderschueren D. 2010. Skeletal sexual dimorphism: relative contribution of sex steroids, GH-IGF1, and mechanical loading. The Journal of endocrinology 207:127-34.

Cao P., Feng F., Dong G., Yu C., Feng S., Song E., Shi G., Liang Y., Liang G. 2015. Estrogen receptor $\alpha$ enhances the transcriptional activity of ETS-1 and promotes the proliferation, migration and invasion of neuroblastoma cell in a ligand dependent manner. BMC cancer $15: 491$.

Casadei R., Pelleri MC., Vitale L., Facchin F., Lenzi L., Canaider S., Strippoli P., Frabetti F. 2011. Identification of housekeeping genes suitable for gene expression analysis in the zebrafish. Gene expression patterns : GEP 11:271-6.

Cohen SP., LaChappelle AR., Walker BS., Lassiter CS. 2014. Modulation of estrogen causes disruption of craniofacial chondrogenesis in Danio rerio. Aquatic toxicology (Amsterdam, Netherlands) 152:113-20.

Cox DA., Helvering LM. 2006. Extracellular matrix integrity: a possible mechanism for differential clinical effects among selective estrogen receptor modulators and estrogens? Molecular and cellular endocrinology 247:53-9.

Craig AM., Denhardt DT. 1991. The murine gene encoding secreted phosphoprotein 1 (osteopontin): promoter structure, activity, and induction in vivo by estrogen and progesterone. Gene 100:163-71.

Deblois G., Hall JA., Perry M-C., Laganière J., Ghahremani M., Park M., Hallett M., Giguère V. 2009. Genome-wide identification of direct target genes implicates estrogen-related receptor alpha as a determinant of breast cancer heterogeneity. Cancer research 69:6149-57.

Dew G., Murphy G., Stanton H., Vallon R., Angel P., Reynolds JJ., Hembry RM. 2000. Localisation of matrix metalloproteinases and TIMP-2 in resorbing mouse bone. Cell and Tissue Research 299:385-394.

Dufty A. 2002. Hormones, developmental plasticity and adaptation. Trends in Ecology \& Evolution 17:190-196.

Eames BF., Singer A., Smith GA., Wood ZA., Yan Y-L., He X., Polizzi SJ., Catchen JM., Rodriguez-Mari A., Linbo T., Raible DW., Postlethwait JH. 2010. UDP xylose synthase 1 is required for morphogenesis and histogenesis of the craniofacial skeleton. Developmental 
534

535

536

537

538

539

540

541

542

543

544

545

546

547

548

549

550

551

552

553

554

555

556

557

558

559

560

561

562

563

564

565

566

567

Eberhart JK., Swartz ME., Crump JG., Kimmel CB. 2006. Early Hedgehog signaling from neural to oral epithelium organizes anterior craniofacial development. Development (Cambridge, England) 133:1069-77.

Elbaradie KBY., Wang Y., Boyan BD., Schwartz Z. 2013. Sex-specific response of rat costochondral cartilage growth plate chondrocytes to $17 \beta$-estradiol involves differential regulation of plasma membrane associated estrogen receptors. Biochimica et biophysica acta 1833:1165-72.

Flores MV., Lam EYN., Crosier P., Crosier K. 2006. A hierarchy of Runx transcription factors modulate the onset of chondrogenesis in craniofacial endochondral bones in zebrafish. Developmental dynamics : an official publication of the American Association of Anatomists 235:3166-76.

Forlano PM., Deitcher DL., Myers DA., Bass AH. 2001. Anatomical distribution and cellular basis for high levels of aromatase activity in the brain of teleost fish: aromatase enzyme and mRNA expression identify glia as source. The Journal of neuroscience : the official journal of the Society for Neuroscience 21:8943-55.

Frasor J., Danes JM., Komm B., Chang KCN., Lyttle CR., Katzenellenbogen BS. 2003. Profiling of estrogen up- and down-regulated gene expression in human breast cancer cells: insights into gene networks and pathways underlying estrogenic control of proliferation and cell phenotype. Endocrinology 144:4562-74.

Fuentes EN., Safian D., Valdés JA., Molina A. 2013. Isolation and selection of suitable reference genes for real-time PCR analyses in the skeletal muscle of the fine flounder in response to nutritional status: assessment and normalization of gene expression of growth-related genes. Fish physiology and biochemistry 39:765-77.

Fujita T., Ohtani J., Shigekawa M., Kawata T., Kaku M., Kohno S., Tsutsui K., Tenjo K., Motokawa M., Tohma Y., Tanne K. 2004. Effects of sex hormone disturbances on craniofacial growth in newborn mice. Journal of dental research 83:250-4.

Fukuhara K., Kariya M., Kita M., Shime H., Kanamori T., Kosaka C., Orii A., Fujita J., Fujii S. 2013. Secreted Frizzled Related Protein 1 Is Overexpressed in Uterine Leiomyomas, Associated with a High Estrogenic Environment and Unrelated to Proliferative Activity. The Journal of Clinical Endocrinology \& Metabolism.

Fushimi S., Wada N., Nohno T., Tomita M., Saijoh K., Sunami S., Katsuyama H. 2009. 17betaEstradiol inhibits chondrogenesis in the skull development of zebrafish embryos. Aquatic toxicology (Amsterdam, Netherlands) 95:292-8.

Ganesan K., Tiwari M., Balachandran C., Manohar BM., Puvanakrishnan R. 2008. Estrogen and 
568

569

570

571

572

573

574

575

576

577

578

579

580

581

582

583

584

585

586

587

588

589

590

591

592

593

594

595

596

597

598

599

600

601

testosterone attenuate extracellular matrix loss in collagen-induced arthritis in rats. Calcified tissue international 83:354-64.

Gilbert SJ., Meakin LB., Bonnet CS., Nowell MA., Ladiges WC., Morton J., Duance VC., Mason DJ. 2014. Deletion of P58(IPK), the Cellular Inhibitor of the Protein Kinases PKR and PERK, Causes Bone Changes and Joint Degeneration in Mice. Frontiers in endocrinology 5:174.

Griffin LB., January KE., Ho KW., Cotter KA., Callard G V. 2013. Morpholino-mediated knockdown of ER $\alpha, E R \beta a$, and ER $\beta b$ mRNAs in zebrafish (Danio rerio) embryos reveals differential regulation of estrogen-inducible genes. Endocrinology 154:4158-69.

Gunter HM., Koppermann C., Meyer A. 2014. Revisiting de Beer's textbook example of heterochrony and jaw elongation in fish: calmodulin expression reflects heterochronic growth, and underlies morphological innovation in the jaws of belonoid fishes. EvoDevo $5: 8$.

Hall JM., Couse JF., Korach KS. 2001. The Multifaceted Mechanisms of Estradiol and Estrogen Receptor Signaling. Journal of Biological Chemistry 276:36869-36872.

Heldring N., Pike A., Andersson S., Matthews J., Cheng G., Hartman J., Tujague M., Ström A., Treuter E., Warner M., Gustafsson J-A. 2007. Estrogen receptors: how do they signal and what are their targets. Physiological reviews 87:905-31.

Hellemans J., Mortier G., De Paepe A., Speleman F., Vandesompele J. 2007. qBase relative quantification framework and software for management and automated analysis of real-time quantitative PCR data. Genome biology 8:R19.

Hillegass JM., Villano CM., Cooper KR., White LA. 2007a. Matrix metalloproteinase-13 is required for zebra fish (Danio rerio) development and is a target for glucocorticoids. Toxicological sciences : an official journal of the Society of Toxicology 100:168-79.

Hillegass JM., Villano CM., Cooper KR., White LA. 2007b. Glucocorticoids Alter Craniofacial Development and Increase Expression and Activity of Matrix Metalloproteinases in Developing Zebrafish (Danio rerio). Toxicological Sciences 102:413-424.

$\mathrm{Hu}$ Y., Albertson RC. 2014. Hedgehog signaling mediates adaptive variation in a dynamic functional system in the cichlid feeding apparatus. Proceedings of the National Academy of Sciences of the United States of America 111:8530-4.

Hu D., Colnot C., Marcucio RS. 2008. Effect of bone morphogenetic protein signaling on development of the jaw skeleton. Developmental Dynamics 237:3727-3737.

Hu D., Helms J. 1999. The role of sonic hedgehog in normal and abnormal craniofacial morphogenesis. Development 126:4873-4884. 
602 Jenei-Lanzl Z., Straub RH., Dienstknecht T., Huber M., Hager M., Grässel S., Kujat R., Angele 603 MK., Nerlich M., Angele P. 2010. Estradiol inhibits chondrogenic differentiation of 604 mesenchymal stem cells via nonclassic signaling. Arthritis and rheumatism 62:1088-96.

605

606

607

608

609

610

611

612

613

614

615

616

617

618

619

620

621

622

623

624

625

626

627

628

629

630

631

632

633

634

635

Jia M., Dahlman-Wright K., Gustafsson J-Å. 2015. Estrogen receptor alpha and beta in health and disease. Best Practice \& Research Clinical Endocrinology \& Metabolism 29:557-568.

Joshi PA., Chang H., Hamel PA. 2006. Loss of Alx4, a stromally-restricted homeodomain protein, impairs mammary epithelial morphogenesis. Developmental biology 297:284-94.

Kubista M., Andrade JM., Bengtsson M., Forootan A., Jonák J., Lind K., Sindelka R., Sjöback R., Sjögreen B., Strömbom L., Ståhlberg A., Zoric N. 2006. The real-time polymerase chain reaction. Molecular aspects of medicine 27:95-125.

Kuratani S., Matsuo I., Aizawa S. 1997. Developmental patterning and evolution of the mammalian viscerocranium: genetic insights into comparative morphology. Developmental dynamics : an official publication of the American Association of Anatomists 209:139-55.

Lam K-K., Cheng P-Y., Hsiao G., Chen S-Y., Shen H-H., Yen M-H., Lee Y-M. 2009. Estrogen deficiency-induced alterations of vascular MMP-2, MT1-MMP, and TIMP-2 in ovariectomized rats. American journal of hypertension 22:27-34.

Lassiter CS., Linney E. 2007. Embryonic expression and steroid regulation of brain aromatase cyp19a1b in zebrafish (Danio rerio). Zebrafish 4:49-57.

Lee Y-H., Saint-Jeannet J-P. 2011. Sox9 function in craniofacial development and disease. Genesis (New York, N.Y. : 2000) 49:200-8.

Lehane DB., McKie N., Russell RG., Henderson IW. 1999. Cloning of a fragment of the osteonectin gene from goldfish, Carassius auratus: its expression and potential regulation by estrogen. General and comparative endocrinology 114:80-7.

Letra A., Silva RM., Motta LG., Blanton SH., Hecht JT., Granjeirol JM., Vieira AR. 2012. Association of MMP3 and TIMP2 promoter polymorphisms with nonsyndromic oral clefts. Birth defects research. Part A, Clinical and molecular teratology 94:540-8.

Lézot F., Chesneau J., Navet B., Gobin B., Amiaud J., Choi Y., Yagita H., Castaneda B., Berdal A., Mueller CG., Rédini F., Heymann D. 2015. Skeletal consequences of RANKL-blocking antibody (IK22-5) injections during growth: mouse strain disparities and synergic effect with zoledronic acid. Bone 73:51-9.

Lin C., Spikings E., Zhang T., Rawson D. 2009. Housekeeping genes for cryopreservation studies on zebrafish embryos and blastomeres. Theriogenology 71:1147-55.

Linville A., Radtke K., Waxman JS., Yelon D., Schilling TF. 2009. Combinatorial roles for zebrafish retinoic acid receptors in the hindbrain, limbs and pharyngeal arches. 
636

637

638

639

640

641

642

643

644

645

646

647

648

649

650

651

652

653

654

655

656

657

658

659

660

661

662

663

664

665

666

667

668

669

Developmental biology 325:60-70.

Liu C., Xin N., Zhai Y., Jiang L., Zhai J., Zhang Q., Qi J. 2014. Reference gene selection for quantitative real-time RT-PCR normalization in the half-smooth tongue sole (Cynoglossus semilaevis) at different developmental stages, in various tissue types and on exposure to chemicals. PloS one 9:e91715.

Lohnes D., Mark M., Mendelsohn C., Dolle P., Dierich A., Gorry P., Gansmuller A., Chambon P. 1994. Function of the retinoic acid receptors (RARs) during development (I). Craniofacial and skeletal abnormalities in RAR double mutants. Development 120:27232748.

Loth SR., Henneberg M. 2001. Sexually dimorphic mandibular morphology in the first few years of life. American journal of physical anthropology 115:179-86.

Lours-Calet C., Alvares LE., El-Hanfy AS., Gandesha S., Walters EH., Sobreira DR., Wotton KR., Jorge EC., Lawson JA., Kelsey Lewis A., Tada M., Sharpe C., Kardon G., Dietrich S. 2014. Evolutionarily conserved morphogenetic movements at the vertebrate head-trunk interface coordinate the transport and assembly of hypopharyngeal structures. Developmental biology 390:231-46.

Lu T., Achari Y., Sciore P., Hart DA. 2006. Estrogen receptor alpha regulates matrix metalloproteinase-13 promoter activity primarily through the AP-1 transcriptional regulatory site. Biochimica et biophysica acta 1762:719-31.

Maddox BK., Garofalo S., Horton WA., Richardson MD., Trune DR. Craniofacial and otic capsule abnormalities in a transgenic mouse strain with a Col2a1 mutation. Journal of craniofacial genetics and developmental biology 18:195-201.

Magnani L., Ballantyne EB., Zhang X., Lupien M. 2011. PBX1 genomic pioneer function drives ER $\alpha$ signaling underlying progression in breast cancer. PLoS genetics 7:e1002368.

Maneix L., Servent A., Porée B., Ollitrault D., Branly T., Bigot N., Boujrad N., Flouriot G., Demoor M., Boumediene K., Moslemi S., Galéra P. 2014. Up-regulation of type II collagen gene by $17 \beta$-estradiol in articular chondrocytes involves Sp1/3, Sox-9, and estrogen receptor $\alpha$. Journal of molecular medicine (Berlin, Germany).

Marazita ML. 2012. The evolution of human genetic studies of cleft lip and cleft palate. Annual review of genomics and human genetics 13:263-83.

Marin-Castaño ME., Elliot SJ., Potier M., Karl M., Striker LJ., Striker GE., Csaky KG., Cousins SW. 2003. Regulation of estrogen receptors and MMP-2 expression by estrogens in human retinal pigment epithelium. Investigative ophthalmology \& visual science 44:50-9.

Marquez Hernandez RA., Ohtani J., Fujita T., Sunagawa H., Kawata T., Kaku M., Motokawa 
670

671

672

673

674

675

676

677

682

683

684

685

686

687

688

689

690

691

692

693

694

695

696

697

698

699

700

701

702

703

M., Tanne K. 2011. Sex hormones receptors play a crucial role in the control of femoral and mandibular growth in newborn mice. The European Journal of Orthodontics 33:564-569.

McCarthy TL., Chang W-Z., Liu Y., Centrella M. 2003. Runx2 integrates estrogen activity in osteoblasts. The Journal of biological chemistry 278:43121-9.

McCurley AT., Callard G V. 2008. Characterization of housekeeping genes in zebrafish: malefemale differences and effects of tissue type, developmental stage and chemical treatment. BMC molecular biology 9:102.

Mosig RA., Dowling O., DiFeo A., Ramirez MCM., Parker IC., Abe E., Diouri J., Aqeel A Al., Wylie JD., Oblander SA., Madri J., Bianco P., Apte SS., Zaidi M., Doty SB., Majeska RJ., Schaffler MB., Martignetti JA. 2007. Loss of MMP-2 disrupts skeletal and craniofacial development and results in decreased bone mineralization, joint erosion and defects in osteoblast and osteoclast growth. Human molecular genetics 16:1113-23.

Ng KP., Datuin JP., Bern HA. 2001. Effects of estrogens in vitro and in vivo on cartilage growth in the tilapia (Oreochromis mossambicus). General and comparative endocrinology 121:295-304.

Nie X., Luukko K., Kettunen P. 2006. BMP signalling in craniofacial development. The International journal of developmental biology 50:511-21.

Nilsson UW., Garvin S., Dabrosin C. 2007. MMP-2 and MMP-9 activity is regulated by estradiol and tamoxifen in cultured human breast cancer cells. Breast cancer research and treatment 102:253-61.

O’Lone R., Frith MC., Karlsson EK., Hansen U. 2004. Genomic targets of nuclear estrogen receptors. Molecular endocrinology (Baltimore, Md.) 18:1859-75.

Obayashi T., Kinoshita K. 2011. COXPRESdb: a database to compare gene coexpression in seven model animals. Nucleic acids research 39:D1016-22.

Oginni FO., Adenekan AT. 2012. Prevention of oro-facial clefts in developing world. Annals of maxillofacial surgery 2:163-9.

Page-McCaw A., Ewald AJ., Werb Z. 2007. Matrix metalloproteinases and the regulation of tissue remodelling. Nature reviews. Molecular cell biology 8:221-33.

Pelayo S., Oliveira E., Thienpont B., Babin PJ., Raldúa D., André M., Piña B. 2012.

Triiodothyronine-induced changes in the zebrafish transcriptome during the eleutheroembryonic stage: implications for bisphenol A developmental toxicity. Aquatic toxicology (Amsterdam, Netherlands) 110-111:114-22.

Petrey AC., Flanagan-Steet H., Johnson S., Fan X., De la Rosa M., Haskins ME., Nairn A V., Moremen KW., Steet R. 2012. Excessive activity of cathepsin K is associated with cartilage 

defects in a zebrafish model of mucolipidosis II. Disease models \& mechanisms 5:177-90.

705

706

707

708

709

710

711

712

713

714

715

716

717

718

719

720

721

722

723

724

725

726

727

728

729

730

731

732

733

734

735

736

737

Pfaffl MW. 2001. A new mathematical model for relative quantification in real-time RT-PCR. Nucleic acids research 29:e45.

Pfaffl MW., Tichopad A., Prgomet C., Neuvians TP. 2004. Determination of stable housekeeping genes, differentially regulated target genes and sample integrity: BestKeeper-Excel-based tool using pair-wise correlations. Biotechnology letters 26:509-15.

Powder KE., Milch K., Asselin G., Albertson RC. 2015. Constraint and diversification of developmental trajectories in cichlid facial morphologies. EvoDevo 6:25.

Qu S., Tucker SC., Zhao Q., deCrombrugghe B., Wisdom R. 1999. Physical and genetic interactions between Alx4 and Cart1. Development (Cambridge, England) 126:359-69.

Ramakers C., Ruijter JM., Deprez RHL., Moorman AFM. 2003. Assumption-free analysis of quantitative real-time polymerase chain reaction (PCR) data. Neuroscience letters 339:626.

Renn J., Schaedel M., Volff J-N., Goerlich R., Schartl M., Winkler C. 2006. Dynamic expression of sparc precedes formation of skeletal elements in the Medaka (Oryzias latipes). Gene 372:208-18.

Roberts RB., Hu Y., Albertson RC., Kocher TD. 2011. Craniofacial divergence and ongoing adaptation via the hedgehog pathway. Proceedings of the National Academy of Sciences of the United States of America 108:13194-9.

Rotllant J., Liu D., Yan Y-L., Postlethwait JH., Westerfield M., Du S-J. 2008. Sparc (Osteonectin) functions in morphogenesis of the pharyngeal skeleton and inner ear. Matrix biology : journal of the International Society for Matrix Biology 27:561-72.

Sanger TJ., Seav SM., Tokita M., Langerhans RB., Ross LM., Losos JB., Abzhanov A. 2014. The oestrogen pathway underlies the evolution of exaggerated male cranial shapes in Anolis lizards. Proceedings. Biological sciences / The Royal Society 281:20140329.

Satoh W., Gotoh T., Tsunematsu Y., Aizawa S., Shimono A. 2006. Sfrp1 and Sfrp2 regulate anteroposterior axis elongation and somite segmentation during mouse embryogenesis. Development (Cambridge, England) 133:989-99.

Schiller V., Wichmann A., Kriehuber R., Schäfers C., Fischer R., Fenske M. 2013. Transcriptome alterations in zebrafish embryos after exposure to environmental estrogens and anti-androgens can reveal endocrine disruption. Reproductive toxicology (Elmsford, N.Y.) 42:210-23.

Sears KE., Goswami A., Flynn JJ., Niswander LA. The correlated evolution of Runx 2 tandem repeats, transcriptional activity, and facial length in carnivora. Evolution \& development 
9:555-65.

739

740

741

742

743

744

745

746

747

748

749

750

751

752

753

754

755

756

757

758

759

760

761

762

763

764

765

766

767

768

769

770

771

772

Selleri L., Depew MJ., Jacobs Y., Chanda SK., Tsang KY., Cheah KS., Rubenstein JL., O'Gorman S., Cleary ML. 2001. Requirement for Pbx1 in skeletal patterning and programming chondrocyte proliferation and differentiation. Development (Cambridge, England) 128:3543-57.

Sgouras DN., Athanasiou MA., Beal GJ., Fisher RJ., Blair DG., Mavrothalassitis GJ. 1995. ERF: an ETS domain protein with strong transcriptional repressor activity, can suppress etsassociated tumorigenesis and is regulated by phosphorylation during cell cycle and mitogenic stimulation. The EMBO journal 14:4781-93.

Shi Y., Liu X., Zhu P., Li J., Sham KWY., Cheng SH., Li S., Zhang Y., Cheng CHK., Lin H. 2013. G-protein-coupled estrogen receptor 1 is involved in brain development during zebrafish (Danio rerio) embryogenesis. Biochemical and biophysical research communications 435:21-7.

Stender JD., Kim K., Charn TH., Komm B., Chang KCN., Kraus WL., Benner C., Glass CK., Katzenellenbogen BS. 2010. Genome-wide analysis of estrogen receptor alpha DNA binding and tethering mechanisms identifies Runx 1 as a novel tethering factor in receptormediated transcriptional activation. Molecular and cellular biology 30:3943-55.

Sumarsono SH., Wilson TJ., Tymms MJ., Venter DJ., Corrick CM., Kola R., Lahoud MH., Papas TS., Seth A., Kola I. 1996. Down's syndrome-like skeletal abnormalities in Ets2 transgenic mice. Nature 379:534-7.

Swartz ME., Nguyen V., McCarthy NQ., Eberhart JK. 2012. Hh signaling regulates patterning and morphogenesis of the pharyngeal arch-derived skeleton. Developmental biology 369:65-75.

Syed FA., Mödder U IL., Fraser DG., Spelsberg TC., Rosen CJ., Krust A., Chambon P., Jameson JL., Khosla S. 2005. Skeletal Effects of Estrogen Are Mediated by Opposing Actions of Classical and Nonclassical Estrogen Receptor Pathways. Journal of Bone and Mineral Research 20:1992-2001.

Szabo-Rogers HL., Smithers LE., Yakob W., Liu KJ. 2010. New directions in craniofacial morphogenesis. Developmental biology 341:84-94.

Tang R., Dodd A., Lai D., McNabb WC., Love DR. 2007. Validation of zebrafish (Danio rerio) reference genes for quantitative real-time RT-PCR normalization. Acta biochimica et biophysica Sinica 39:384-90.

Tankó LB., Søndergaard B-C., Oestergaard S., Karsdal MA., Christiansen C. 2008. An update review of cellular mechanisms conferring the indirect and direct effects of estrogen on articular cartilage. Climacteric : the journal of the International Menopause Society 11:4- 
773

774

775

776

777

778

779

780

781

782

783

784

785

786

787

788

789

790

791

792

793

794

795

796

797

798

799

800

801

802

803

804

805

806

16.

Thisse B., Pflumio S., Fürthauer M., Loppin B., Heyer V., Degrave A., Woehl R., Lux A., Steffan T., Charbonnier XQ., And., Thisse C. 2001. Expression of the zebrafish genome during embryogenesis (NIH R01 RR15402). ZFIN Direct Data Submission (http://zfin.org).

Thisse B., Heyer V., Lux A., Alunni V., Degrave A., Seiliez I., Kirchner J., Parkhill J-P., Thisse C. 2004. Spatial and temporal expression of the zebrafish genome by large-scale in situ hybridization screening. Methods in cell biology 77:505-19.

Thisse, C., and Thisse B. 2005. High Throughput Expression Analysis of ZF-Models Consortium Clones. ZFIN Direct Data Submission (http://zfin.org).

Trainor PA., Melton KR., Manzanares M. 2003. Origins and plasticity of neural crest cells and their roles in jaw and craniofacial evolution. The International journal of developmental biology 47:541-53.

Trevant B., Gaur T., Hussain S., Symons J., Komm BS., Bodine PVN., Stein GS., Lian JB. 2008. Expression of secreted frizzled related protein 1, a Wnt antagonist, in brain, kidney, and skeleton is dispensable for normal embryonic development. Journal of cellular physiology 217:113-26.

Troen BR. 2006. The regulation of cathepsin K gene expression. Annals of the New York Academy of Sciences 1068:165-72.

Tüshaus L., Hopert A-C., Strunck E., Schubert C., Wünsche W., Vollmer G. 2003. Estrogenic and antiestrogenic regulation of MMP-2 and MMP-13 mRNA in RUCA-I endometrial tumor cells in vitro and in vivo. Cancer Letters 198:99-106.

Twigg SRF., Vorgia E., McGowan SJ., Peraki I., Fenwick AL., Sharma VP., Allegra M., Zaragkoulias A., Sadighi Akha E., Knight SJL., Lord H., Lester T., Izatt L., Lampe AK., Mohammed SN., Stewart FJ., Verloes A., Wilson LC., Healy C., Sharpe PT., Hammond P., Hughes J., Taylor S., Johnson D., Wall SA., Mavrothalassitis G., Wilkie AOM. 2013. Reduced dosage of ERF causes complex craniosynostosis in humans and mice and links ERK1/2 signaling to regulation of osteogenesis. Nature genetics 45:308-13.

Vanacker JM., Delmarre C., Guo X., Laudet V. 1998. Activation of the osteopontin promoter by the orphan nuclear receptor estrogen receptor related alpha. Cell growth \& differentiation : the molecular biology journal of the American Association for Cancer Research 9:1007-14.

Vandesompele J., De Preter K., Pattyn F., Poppe B., Van Roy N., De Paepe A., Speleman F. 2002. Accurate normalization of real-time quantitative RT-PCR data by geometric averaging of multiple internal control genes. Genome biology 3:RESEARCH0034.

Venkatesh B., Lee AP., Ravi V., Maurya AK., Lian MM., Swann JB., Ohta Y., Flajnik MF., 
807

808

809

810

811

812

813

814

815

816

817

818

819

820

821

822

823

824

825

826

827

828

829

830

831

832

833

834

835

836

837

838

839

840

841

Sutoh Y., Kasahara M., Hoon S., Gangu V., Roy SW., Irimia M., Korzh V., Kondrychyn I., Lim ZW., Tay B-H., Tohari S., Kong KW., Ho S., Lorente-Galdos B., Quilez J., MarquesBonet T., Raney BJ., Ingham PW., Tay A., Hillier LW., Minx P., Boehm T., Wilson RK., Brenner S., Warren WC. 2014. Elephant shark genome provides unique insights into gnathostome evolution. Nature 505:174-9.

Wang E., Wang K., Chen D., Wang J., He Y., Long B., Yang L., Yang Q., Geng Y., Huang X., Ouyang P., Lai W. 2015. Evaluation and Selection of Appropriate Reference Genes for Real-Time Quantitative PCR Analysis of Gene Expression in Nile Tilapia (Oreochromis niloticus) during Vaccination and Infection. International journal of molecular sciences 16:9998-10015.

Wang J., Ma X. 2012. Effects of estrogen and progestin on expression of MMP-2 and TIMP-2 in a nude mouse model of endometriosis. Clinical and experimental obstetrics \& gynecology 39:229-33.

Warner KE., Jenkins JJ. 2007. Effects of 17alpha-ethinylestradiol and bisphenol A on vertebral development in the fathead minnow (Pimephales promelas). Environmental toxicology and chemistry / SETAC 26:732-7.

Werb Z., Chin JR. 1998. Extracellular matrix remodeling during morphogenesis. Annals of the New York Academy of Sciences 857:110-8.

Whyte MP., Obrecht SE., Finnegan PM., Jones JL., Podgornik MN., McAlister WH., Mumm S. 2002. Osteoprotegerin deficiency and juvenile Paget's disease. The New England journal of medicine 347:175-84.

Yamamoto T., Saatcioglu F., Matsuda T. 2013. Cross-Talk between Bone Morphogenic Proteins and Estrogen Receptor Signaling. Endocrinology.

Yan Y-L., Willoughby J., Liu D., Crump JG., Wilson C., Miller CT., Singer A., Kimmel C., Westerfield M., Postlethwait JH. 2005. A pair of Sox: distinct and overlapping functions of zebrafish sox9 co-orthologs in craniofacial and pectoral fin development. Development (Cambridge, England) 132:1069-83.

Yokota T., Oritani K., Garrett KP., Kouro T., Nishida M., Takahashi I., Ichii M., Satoh Y., Kincade PW., Kanakura Y. 2008. Soluble Frizzled-Related Protein 1 Is Estrogen Inducible in Bone Marrow Stromal Cells and Suppresses the Earliest Events in Lymphopoiesis. The Journal of Immunology 181:6061-6072.

Zhou S., Turgeman G., Harris SE., Leitman DC., Komm BS., Bodine PVN., Gazit D. 2003. Estrogens activate bone morphogenetic protein-2 gene transcription in mouse mesenchymal stem cells. Molecular endocrinology (Baltimore, Md.) 17:56-66. 


\section{1}

Expression analysis of candidate reference genes in developing heads of zebrafish larvae across control and $\mathrm{E}_{2}$ treated groups.

(A) Expression profiles of candidate reference genes in raw Cq values for all samples ( 3 treatments for each of 5 larval stages and with 3 biological replicates). The middle line denotes the median and boxes indicate the 25/75 percentiles. (B) Expression differences of candidate reference genes in the head of zebrafish during the larval development and three $E_{2}$ treatment groups. Fold changes in expression calculated from the qPCR data, were subjected to ANOVA and Tukey's HSD analysis to test the expression differences amongst three treatment groups (control, $2 \mu \mathrm{M}$ and $5 \mu \mathrm{M}$ ) and across five larval stages ( 3 to $7 \mathrm{dpf}$ ). White boxes represent low expression, while black boxes represent high expression. Two or more steps of shade differences in the boxes represent significantly different expression between the samples (alpha $=0.05)$. NS $=$ not significant. 
A

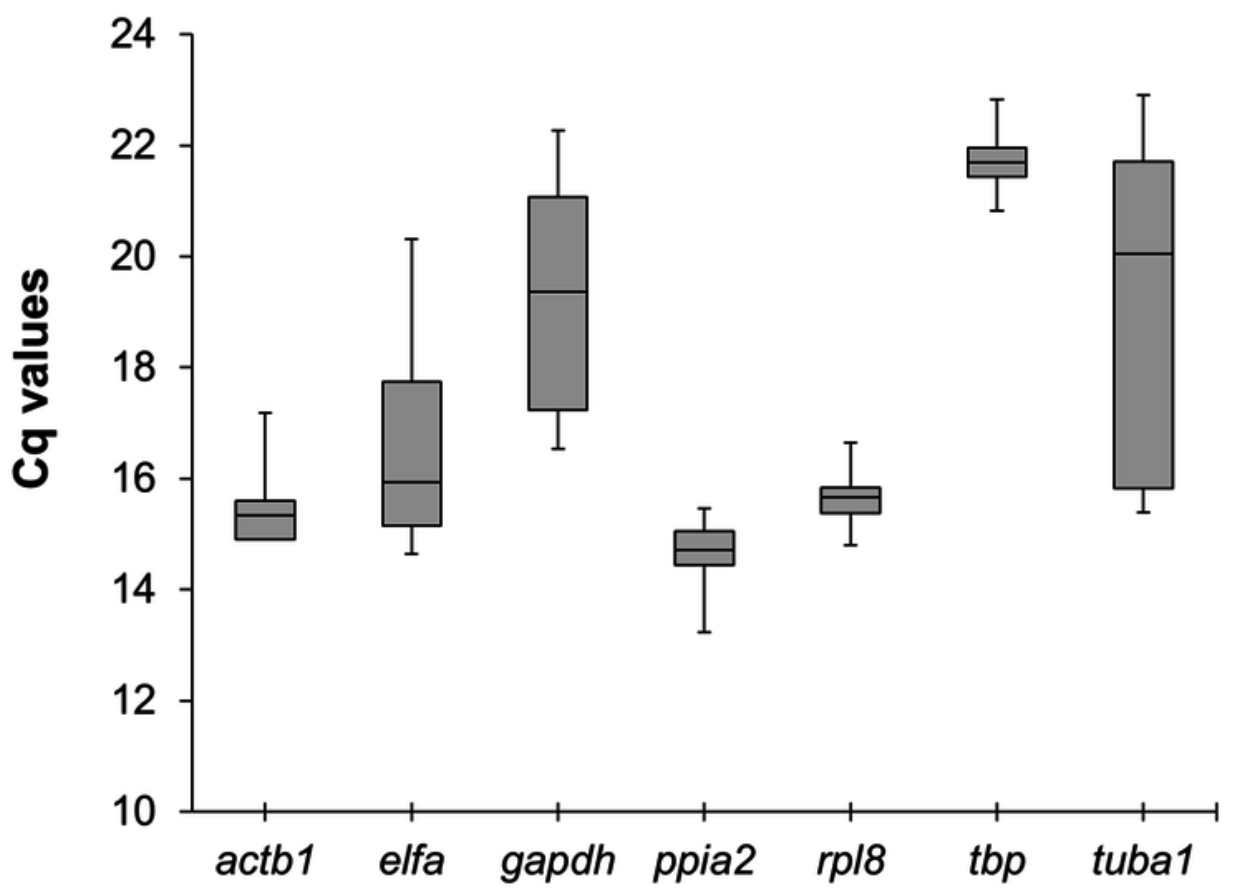

Reference genes

B

\begin{tabular}{cc|c|c|c|c|c|c|c|c|c|}
\hline Gene & $\begin{array}{c}\text { ANOVA } \\
\text { treatments }\end{array}$ & \multicolumn{2}{c}{$\begin{array}{c}\text { HSD } \\
\text { treatments }\end{array}$} & \multicolumn{3}{c}{$\begin{array}{c}\text { ANOVA } \\
\text { larval stage }\end{array}$} & \multicolumn{4}{c}{ HSD } \\
\hline larval stage
\end{tabular}




\section{2}

Expression differences of two estrogen receptors and components of hedgehog signaling pathway in developing heads of zebrafish larvae across control and $E_{2}$ treated groups.

Expression of esrra, esr1, ptch1, ptch2, shha and shhb was examined with qPCR and normalised using three highest ranked reference genes (ppia2, rp/8 and tbp). For analysis of relative expression levels for each target gene a replicate of the control group at $3 \mathrm{dpf}$ was set to one. The white, grey, and black bars in each graph represent expression levels for control, $2 \mu \mathrm{M} \mathrm{E}_{2}$ treated and $5 \mu \mathrm{M} \mathrm{E}_{2}$ treated groups respectively. Statistical differences of each treatment group versus the others are shown in white, grey, and black circles representing higher expressed than control, $2 \mu \mathrm{M} E_{2}$ treated and $5 \mu M E_{2}$ treated groups respectively $(P<$ 0.05). Error bars represent standard deviation calculated from three biological replicates. Each biological replicate is from a homogenate of 30 heads.

esrra

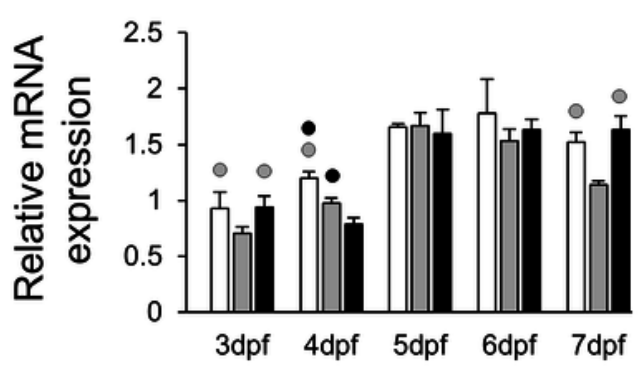

ptch2

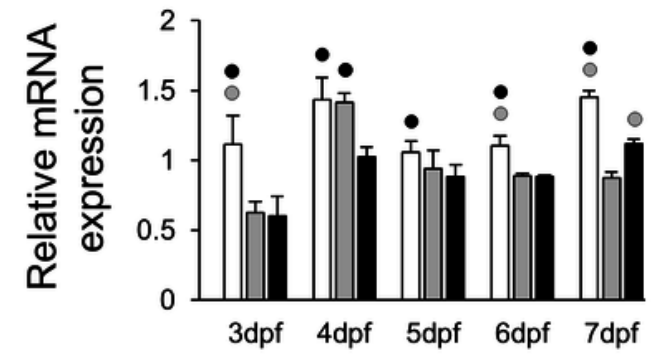

Larval stage esr1

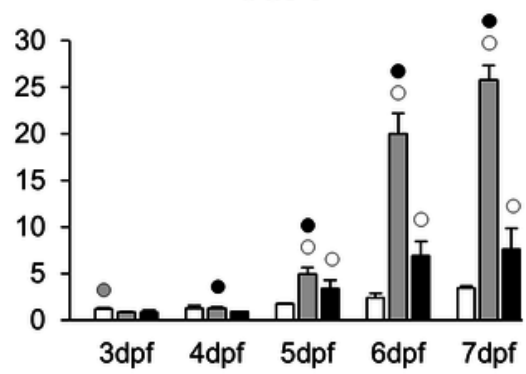

shha

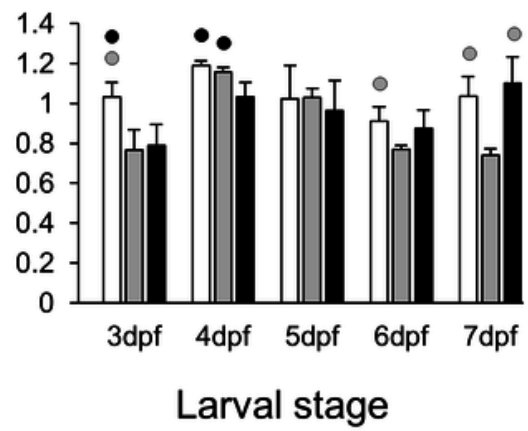

ptch1

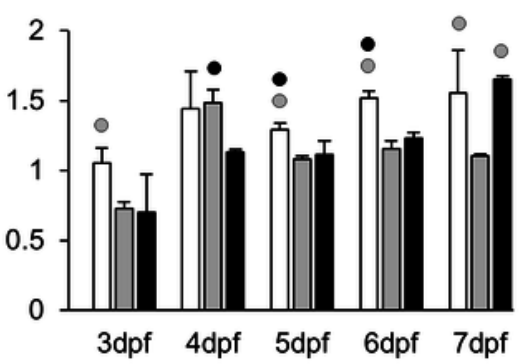

shhb

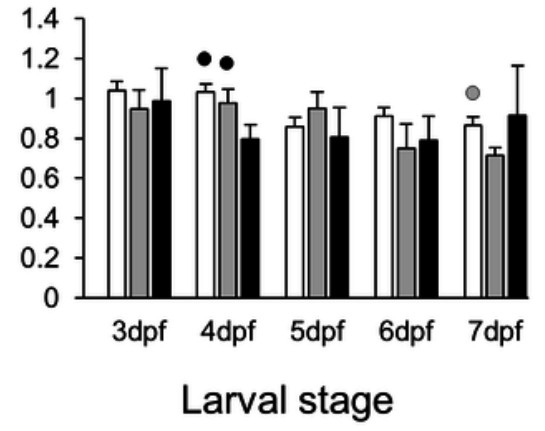




\section{3}

Expression differences of six potential skeletogenic targets of estrogen pathway in developing heads of zebrafish larvae across control and $E_{2}$ treated groups.

Expression of bmp2a, bmp2b, opg, rankl, runx $2 b$ and sox $9 b$ was examined with qPCR and normalised using three highest ranked reference genes (ppia2, rp/8 and tbp). For analysis of relative expression levels for each target gene a replicate of the control group at 3dpf was set to one. The white, grey, and black bars in each graph represent expression levels for control, $2 \mu \mathrm{ME} E_{2}$ treated and $5 \mu \mathrm{ME}_{2}$ treated groups respectively. Statistical differences of each treatment group versus the others are shown in white, grey, and black circles representing higher expressed than control , $2 \mu M E_{2}$ treated and $5 \mu M E_{2}$ treated groups respectively $(P<$ $0.05)$. Error bars represent standard deviation calculated from three biological replicates. Each biological replicate was made from a homogenate of 30 heads.

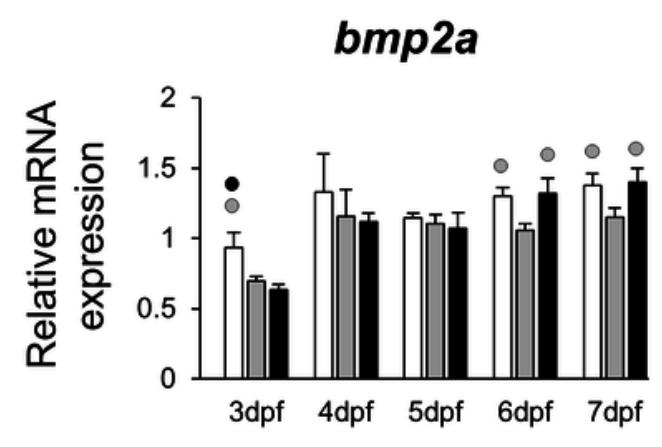

rankl

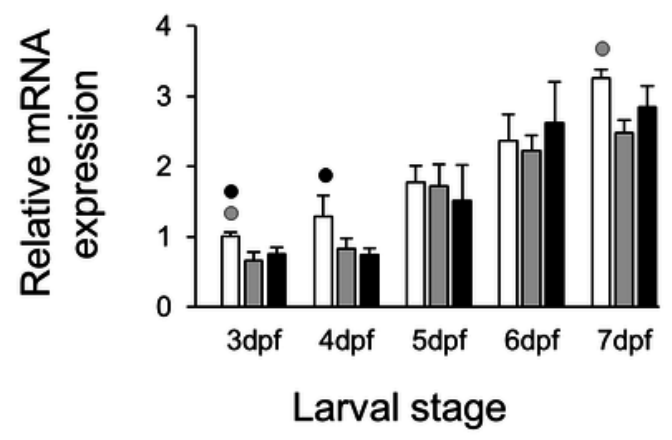

bmp2b

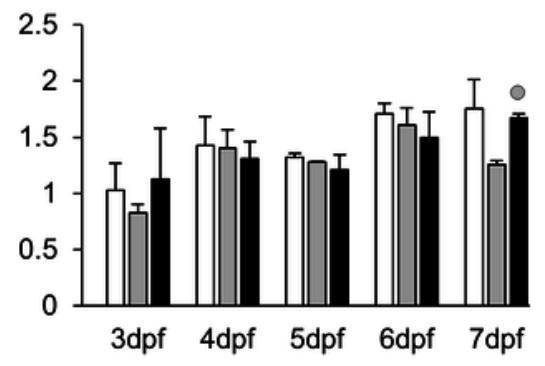

runx2b

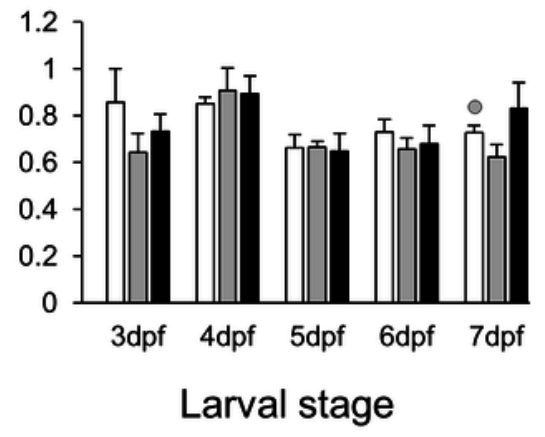

opg

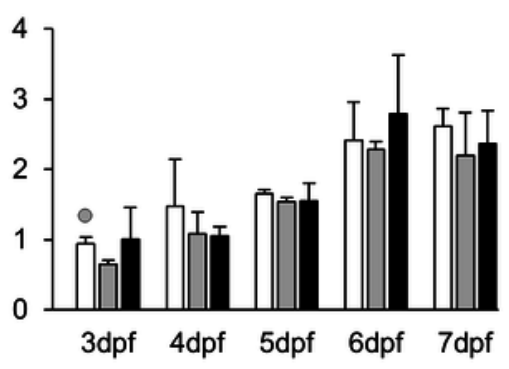

sox9b

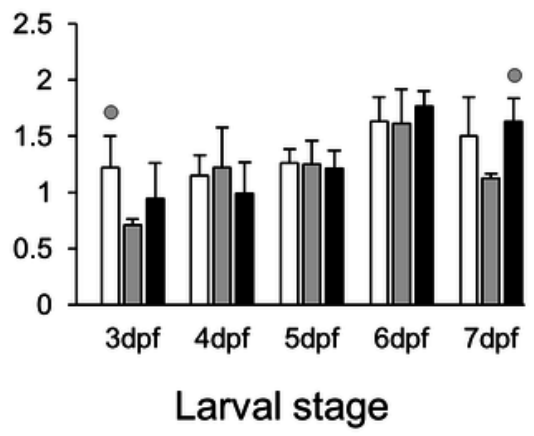




\section{4}

Expression differences of eight potential targets of estrogen pathway involved in skeletal ECM formation examined during zebrafish larval head development across control and $E_{2}$ treated groups.

Expression of col2ala, ctsk, mmp2, mmp9, mmp13, sparc, spp1 and timp2 was examined with qPCR and normalised using three highest ranked reference genes (ppia2, rp/8 and tbp). For analysis of relative expression levels for each target gene a replicate of the control group at $3 \mathrm{dpf}$ was set to one. The white, grey, and black bars in each graph represent expression levels for control, $2 \mu \mathrm{ME}_{2}$ treated and $5 \mu \mathrm{M} \mathrm{E}_{2}$ treated groups respectively. Statistical differences of each treatment group versus the others are shown in white, grey, and black circles representing higher expressed than control, $2 \mu \mathrm{ME}_{2}$ treated and $5 \mu \mathrm{ME}_{2}$ treated groups respectively $(P<0.05)$. Error bars represent standard deviation calculated from three biological replicates. Each biological replicate was made from a homogenate of 30 heads. 


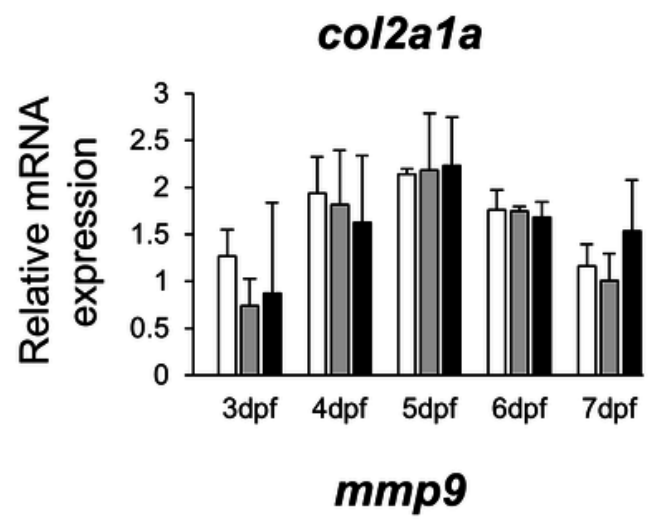

ctsk

mmp2
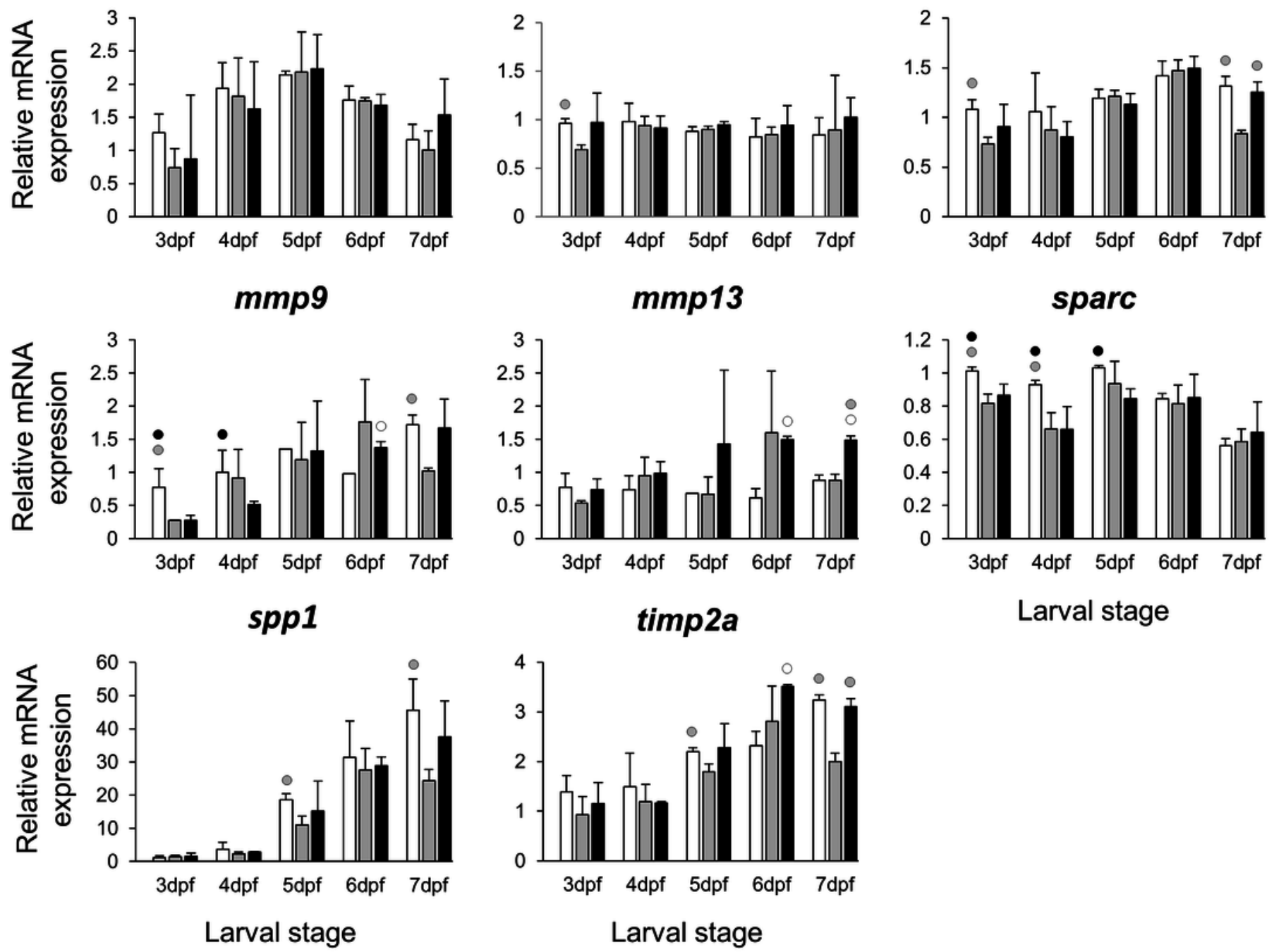


\section{5}

Expression differences of eight other potential targets of estrogen pathway involved in jaw skeletal elongation examined during zebrafish larval head development across control and $\mathrm{E}_{2}$ treated groups.

Expression of $a l x 4, d \mid x 1$, erf, ets2, pbx1a, pbx1b, rarab and sfrp1a was examined with qPCR and normalised using three best ranked reference genes (ppia2, rp/8 and tbp). For analysis of relative expression levels for each target gene a replicate of the control group at 3dpf was set to one. The white, grey, and black bars in each graph represent expression levels for control, $2 \mu \mathrm{M} \mathrm{E}_{2}$ treated and $5 \mu \mathrm{ME}_{2}$ treated groups respectively. Statistical differences of each treatment group versus the others are shown in white, grey, and black circles representing higher expressed than control, $2 \mu M E_{2}$ treated and $5 \mu M E_{2}$ treated groups respectively $(P<$ 0.05). Error bars represent standard deviation calculated from three biological replicates. Each biological replicate was made from a homogenate of 30 heads. 

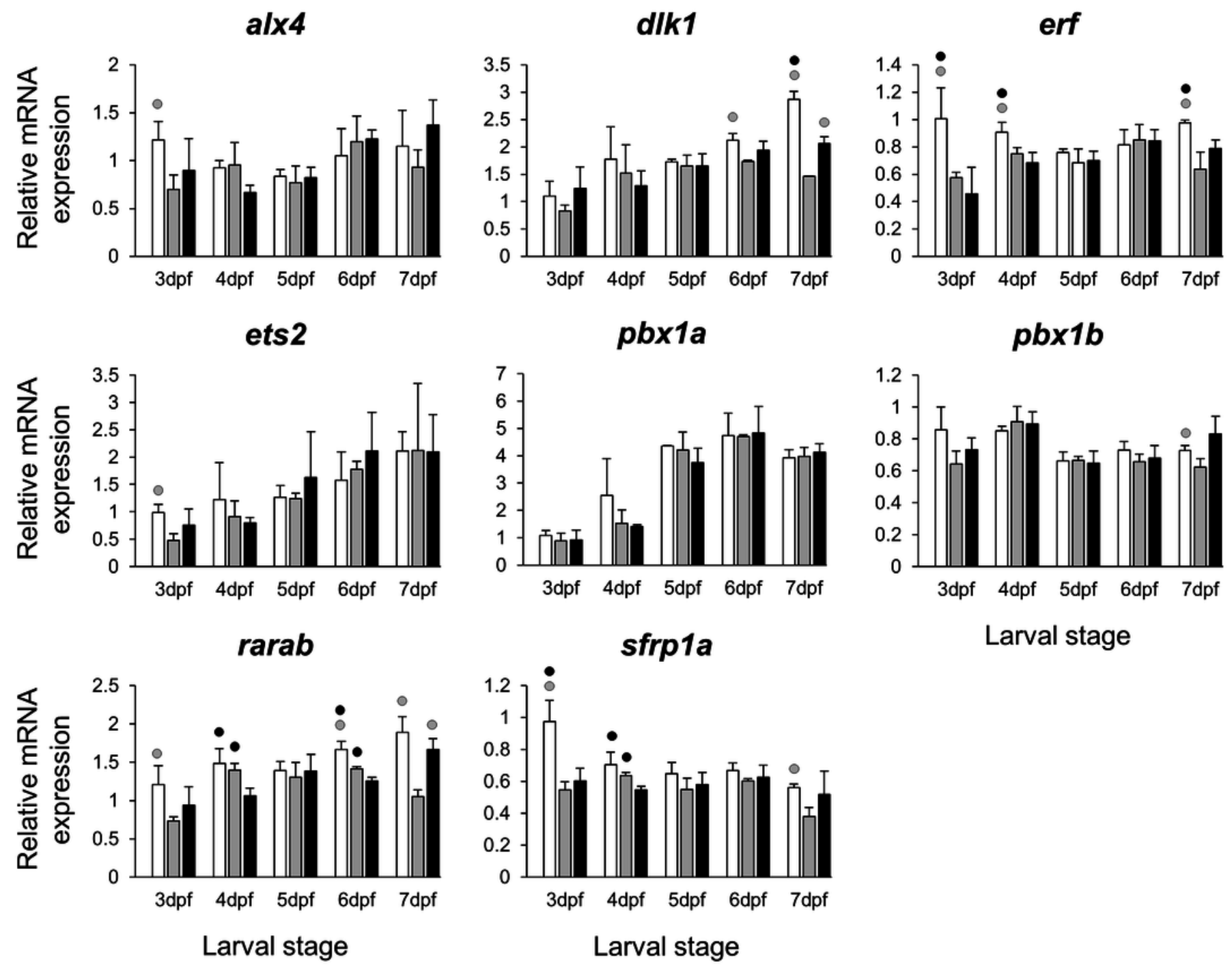
6

Expression differences of esr1 coexpressed genes in developing heads of zebrafish larvae across control and $E_{2}$ treated groups.

Expression levels of eleven candidate genes coexpresed with esr1, based on data from COXPRESdb in zebrafish, were examined with qPCR and normalised using three best ranked reference genes (ppia2, rp/8 and tbp). For analysis of relative expression levels for each target gene a replicate of the control group at $3 \mathrm{dpf}$ was set to one. The white, grey, and black bars in each graph represent expression levels for control, $2 \mu \mathrm{M} E_{2}$ treated and $5 \mu \mathrm{M} \mathrm{E}_{2}$ treated groups respectively. Statistical differences of each treatment group versus the others are shown in white, grey, and black circles representing higher expressed than in control, $2 \mu \mathrm{M} E_{2}$ treated and $5 \mu \mathrm{M} \mathrm{E}_{2}$ treated groups respectively $(P<0.05)$. Error bars represent standard deviation calculated from three biological replicates. Each biological replicate is based on a homogenate of 30 heads.

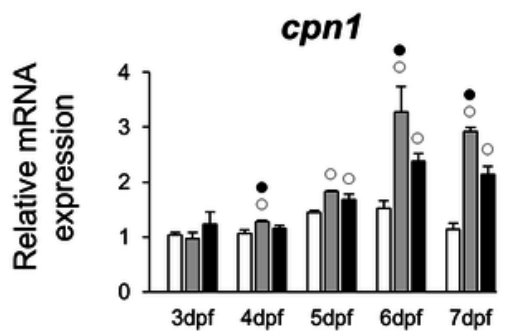

Iman1

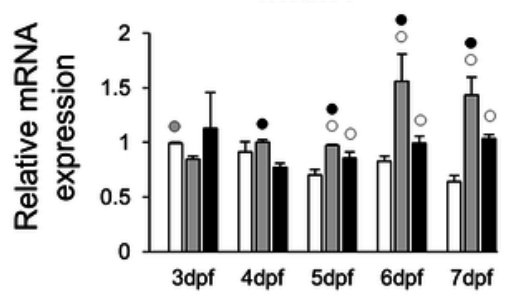

ssr1

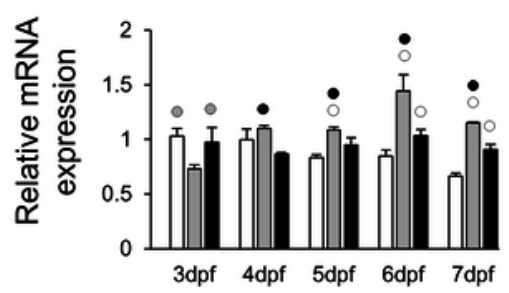

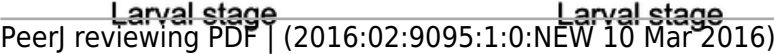

cyr61

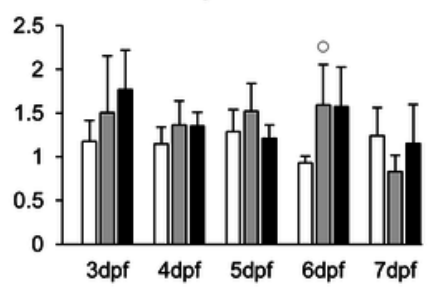

nr5a2

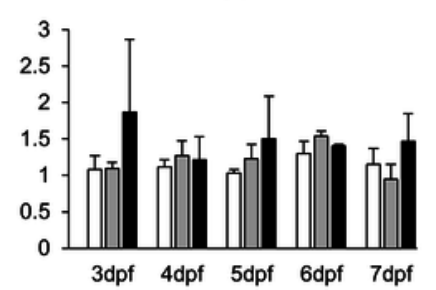

tram1

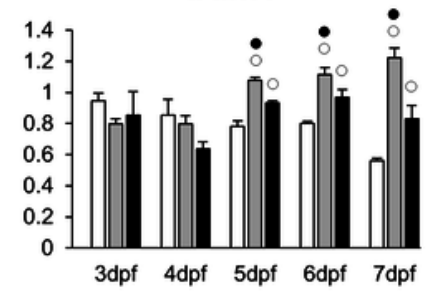

016)

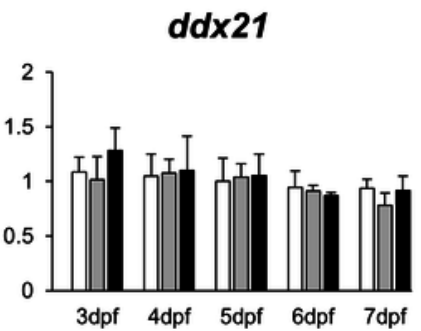

rrbp1a

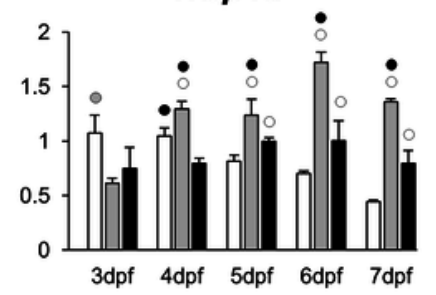

xbp1

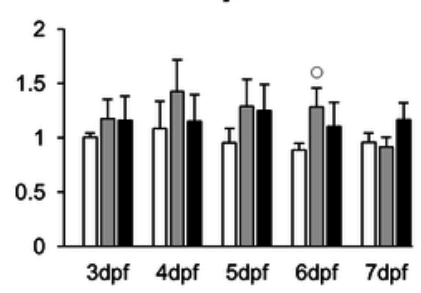

Larval stage

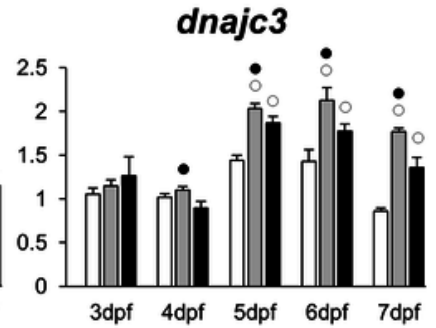

sec61a1

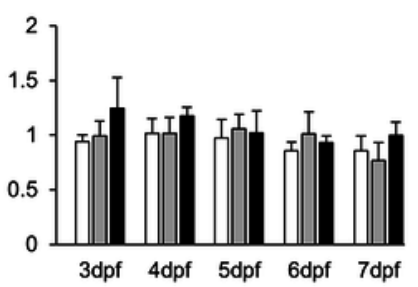

Larval stage 


\section{Table $\mathbf{1}$ (on next page)}

Selected putative estrogen-regulated candidate genes, and available literature indicating their role in craniofacial development/skeletal formation in zebrafish or other vertebrates. 


\begin{tabular}{|c|c|c|c|c|c|c|}
\hline \multirow{2}{*}{$\begin{array}{c}\text { Gene } \\
\text { Symbol }\end{array}$} & \multirow{2}{*}{ Related Function } & \multirow{2}{*}{$\begin{array}{c}\text { Viscerocranial } \\
\text { expression during } \\
\text { zebrafish development }\end{array}$} & \multirow{2}{*}{$\begin{array}{c}\text { Potential } \\
\text { Estrogen } \\
\text { Responsive * }\end{array}$} & \multicolumn{2}{|c|}{ Craniofacial skeletogenesis } & \multirow{2}{*}{ References } \\
\hline & & & & $\begin{array}{c}\text { Shortened } \\
\text { snout } * *\end{array}$ & $\begin{array}{l}\text { Other } \\
\text { effects }\end{array}$ & \\
\hline alx4 & $\begin{array}{c}\text { Patterning and } \\
\text { development of } \\
\text { craniofacial skeleton }\end{array}$ & + & + & + & + & $\begin{array}{c}\text { (Qu et al., 1999; Joshi, Chang \& } \\
\text { Hamel, 2006; Lours-Calet et al., } \\
\text { 2014) }\end{array}$ \\
\hline $\begin{array}{r}\text { bmp2 } \\
(\mathrm{a} / \mathrm{b})\end{array}$ & $\begin{array}{l}\text { Induction of bone and } \\
\text { cartilage formation }\end{array}$ & + & + & $?$ & + & $\begin{array}{l}\text { (Thisse et al., 2001, 2004; Zhou } \\
\text { et al., 2003; Nie, Luukko \& } \\
\text { Kettunen, 2006; Hu, Colnot \& } \\
\text { Marcucio, 2008; Yamamoto, } \\
\text { Saatcioglu \& Matsuda, 2013) }\end{array}$ \\
\hline col2ala & $\begin{array}{c}\text { Extracellular matrix } \\
\text { formation in cartilaginous } \\
\text { tissues }\end{array}$ & + & + & + & + & $\begin{array}{l}\text { (Maddox et al.; Eames et al., } \\
\text { 2010; Maneix et al., 2014) }\end{array}$ \\
\hline ctsk & $\begin{array}{l}\text { Bone remodelling and } \\
\text { resorption }\end{array}$ & + & + & + & + & $\begin{array}{c}\text { (Thisse et al., 2004; Troen, 2006; } \\
\text { Petrey et al., 2012; Ahi et al., } \\
\text { 2014) }\end{array}$ \\
\hline$d l k 1$ & $\begin{array}{l}\text { Differentiation of skeletal } \\
\text { cells }\end{array}$ & $?$ & + & + & + & (Abdallah et al., 2011) \\
\hline erf & $\begin{array}{c}\text { Regulation of cellular } \\
\text { senescence }\end{array}$ & $?$ & + & + & + & $\begin{array}{c}\text { (Frasor et al., 2003; Twigg et al., } \\
\text { 2013) }\end{array}$ \\
\hline esrra & $\begin{array}{l}\text { Regulation of estrogen } \\
\text { mediated pathway }\end{array}$ & + & + & $?$ & + & $\begin{array}{c}\text { (Bonnelye \& Aubin, 2005; } \\
\text { Bonnelye et al., 2007; Auld et al., } \\
\text { 2012) }\end{array}$ \\
\hline esrl & $\begin{array}{l}\text { A ligand-activated } \\
\text { receptor for estrogen }\end{array}$ & $?$ & + & $?$ & + & $\begin{array}{l}\text { (O’Lone et al., 2004; Syed et al., } \\
\text { 2005) }\end{array}$ \\
\hline ets 2 & $\begin{array}{c}\text { Regulation of } \\
\text { developmental genes and } \\
\text { apoptosis }\end{array}$ & $?$ & + & + & + & $\begin{array}{l}\text { (Sumarsono et al., 1996; Deblois } \\
\text { et al., 2009; Ahi et al., 2014) }\end{array}$ \\
\hline $\begin{array}{c}m m p \\
(2 / 9 / 13)\end{array}$ & $\begin{array}{l}\text { Extracellular matrix } \\
\text { formation and signal } \\
\text { transduction }\end{array}$ & + & + & + & + & $\begin{array}{l}\text { (Breckon et al., 1999; Tüshaus et } \\
\text { al., 2003; Marin-Castaño et al., } \\
\text { 2003; Lu et al., 2006; Hillegass et } \\
\text { al., 2007a,b; Mosig et al., 2007; } \\
\text { Nilsson, Garvin \& Dabrosin, } \\
\text { 2007) }\end{array}$ \\
\hline opg & $\begin{array}{l}\text { Negative regulation of } \\
\text { bone resorption }\end{array}$ & $?$ & + & $?$ & + & $\begin{array}{c}\text { (Bord et al., 2003)(Whyte et al., } \\
\text { 2002) }\end{array}$ \\
\hline $\begin{array}{l}p b x 1 \\
(\mathrm{a} / \mathrm{b})\end{array}$ & $\begin{array}{l}\text { co-ordination of } \\
\text { chondrocyte proliferation } \\
\text { and differentiation }\end{array}$ & + & + & + & + & $\begin{array}{c}\text { (Selleri et al., 2001; Thisse, C., } \\
\text { and Thisse, 2005; Magnani et al., } \\
\text { 2011) }\end{array}$ \\
\hline $\begin{array}{l}\text { ptch } \\
(1 / 2)\end{array}$ & $\begin{array}{l}\text { Receptors for hedgehog } \\
\text { signalling pathway }\end{array}$ & + & + & + & + & $\begin{array}{c}\text { (Fushimi et al., 2009; Roberts et } \\
\text { al., 2011) }\end{array}$ \\
\hline rankl & $\begin{array}{c}\text { Osteoclast differentiation } \\
\text { and activation }\end{array}$ & $?$ & + & $?$ & + & $\begin{array}{l}\text { (Bord et al., 2003; Lézot et al., } \\
\text { 2015) }\end{array}$ \\
\hline rarab & $\begin{array}{l}\text { A receptor for retinoic } \\
\text { acid signalling pathway }\end{array}$ & + & + & + & + & $\begin{array}{l}\text { (Lohnes et al., 1994; O’Lone et } \\
\text { al., 2004; Linville et al., 2009) }\end{array}$ \\
\hline $\operatorname{runx} 2 b$ & $\begin{array}{c}\text { Osteoblast differentiation } \\
\text { and skeletal } \\
\text { morphogenesis }\end{array}$ & + & + & + & + & $\begin{array}{l}\text { (Sears et al.; McCarthy et al., } \\
\text { 2003; Flores et al., 2006) }\end{array}$ \\
\hline sfrpla & $\begin{array}{l}\text { A soluble modulator of } \\
\text { Wnt signalling pathway }\end{array}$ & $?$ & + & + & + & $\begin{array}{l}\text { (Satoh et al., 2006; Trevant et al., } \\
\text { 2008; Yokota et al., 2008; } \\
\text { Fukuhara et al., 2013; Ahi et al., } \\
\text { 2014) }\end{array}$ \\
\hline
\end{tabular}




\begin{tabular}{|c|c|c|c|c|c|c|}
\hline $\begin{array}{l}S h h \\
(\mathrm{a} / \mathrm{b})\end{array}$ & $\begin{array}{l}\text { Activators of hedgehog } \\
\text { signalling pathway }\end{array}$ & + & $?$ & $?$ & + & $\begin{array}{c}\text { (Hu \& Helms, 1999; Swartz et } \\
\text { al., 2012) }\end{array}$ \\
\hline $\operatorname{sox} 9 b$ & $\begin{array}{l}\text { Chondrocyte } \\
\text { differentiation }\end{array}$ & + & + & $?$ & + & $\begin{array}{l}\text { (Yan et al., 2005; Bonnelye et al., } \\
\text { 2007; Lee \& Saint-Jeannet, 2011) }\end{array}$ \\
\hline sparc & $\begin{array}{c}\text { Extracellular matrix } \\
\text { synthesis and regulation } \\
\text { of cell growth }\end{array}$ & + & + & + & + & $\begin{array}{l}\text { (Lehane et al., 1999; Renn et al., } \\
\text { 2006; Rotllant et al., 2008) }\end{array}$ \\
\hline sppl & $\begin{array}{l}\text { Attachment of osteoclasts } \\
\text { to ECM in bone }\end{array}$ & + & + & + & + & $\begin{array}{c}\text { (Craig \& Denhardt, 1991; } \\
\text { Vanacker et al., 1998; Venkatesh } \\
\text { et al., 2014) }\end{array}$ \\
\hline timp $2 a$ & $\begin{array}{c}\text { Inhibition of mmps and } \\
\text { regulation of tissue } \\
\text { homeostasis }\end{array}$ & $?$ & + & + & $?$ & $\begin{array}{l}\text { (Dew et al., 2000; Lam et al., } \\
\text { 2009; Letra et al., 2012; Wang \& } \\
\text { Ma, 2012; Ahi et al., 2014) }\end{array}$ \\
\hline
\end{tabular}

* The estrogen responsiveness indicates either transcriptional regulation or transactivation and the related information are mainly obtained from different model vertebrates, such as human and mouse, than teleost fishes.

** The shortened snout indicates the skeletal effects resulted from decrease in the length or changes in morphology of viscerocranial skeletal elements in different vertebrate species. This could bear a resemblance to estrogen mediated shorter snout and flatter face phenotype in zebrafish.

1

2 


\section{Table 2 (on next page)}

Ranking and statistical analyses of candidate reference genes using BestKeeper, geNorm and NormFinder. 
1

\begin{tabular}{|c|c|c|c|c|c|c|c|}
\hline \multicolumn{4}{|c|}{ BestKeeper } & \multicolumn{2}{|c|}{ geNorm } & \multicolumn{2}{|c|}{ NormFinder } \\
\hline Ranking & $\mathbf{r}$ & Ranking & SD & Ranking & M & Ranking & SV \\
\hline rpl8 & 0.908 & $t b p$ & 0.294 & ppia2 & 0.111 & rpl8 & 0.137 \\
\hline$t b p$ & 0.863 & rpl8 & 0.343 & rpl8 & 0.125 & ppia2 & 0.154 \\
\hline ppia2 & 0.862 & ppia2 & 0.350 & $t b p$ & 0.133 & $t b p$ & 0.157 \\
\hline$a c t b 1$ & 0.687 & $a c t b 1$ & 0.396 & $a c t b 1$ & 0.26 & $a c t b 1$ & 0.287 \\
\hline eflla & 0.331 & eflla & 1.358 & eflla & 0.739 & eflla & 1.128 \\
\hline tubal & 0.201 & gapdh & 1.690 & gapdh & 1.084 & gapdh & 1.382 \\
\hline gapdh & 0.148 & tubal & 2.773 & tubal & 1.482 & tubal & 2.088 \\
\hline
\end{tabular}

2

3 Abbreviations: $\mathrm{SD}=$ Standard deviation, $\mathrm{r}=$ Pearson product-moment correlation coefficient, $\mathrm{SV}$

4 = stability value, $M=M$ value of stability. 